\title{
Aberrant Phex function in osteoblasts and osteocytes alone underlies murine X-linked hypophosphatemia
}

\author{
Baozhi Yuan, ${ }^{1}$ Masanori Takaiwa, ${ }^{1}$ Thomas L. Clemens, ${ }^{2}$ Jian Q. Feng, ${ }^{3}$ Rajiv Kumar, ${ }^{4}$ \\ Peter S. Rowe, ${ }^{5}$ Yixia Xie, ${ }^{3}$ and Marc K. Drezner ${ }^{1}$
}

\begin{abstract}
1Department of Medicine, University of Wisconsin, and GRECC, William F. Middleton Veterans Administration Hospital, Madison, Wisconsin, USA. 2Department of Pathology, University of Alabama, Birmingham, Alabama, USA. ${ }^{2}$ Department of Medicine, University of Missouri, Kansas City, Missouri, USA. ${ }^{4}$ Department of Medicine, Mayo Clinic, Rochester, Minnesota, USA. ${ }^{5}$ Department of Medicine, University of Kansas, Kansas City, Kansas, USA.
\end{abstract}

Patients with X-linked hypophosphatemia (XLH) and the hyp-mouse, a model of XLH characterized by a deletion in the Phex gene, manifest hypophosphatemia, renal phosphate wasting, and rickets/osteomalacia. Cloning of the PHEX/Phex gene and mutations in affected patients and hyp-mice established that alterations in PHEX/Phex expression underlie XLH. Although PHEX/Phex expression occurs primarily in osteoblast lineage cells, transgenic Phex expression in hyp-mouse osteoblasts fails to rescue the phenotype, suggesting that Phex expression at other sites underlies XLH. To establish whether abnormal Phex in osteoblasts and/or osteocytes alone generates the HYP phenotype, we created mice with a global Phex knockout (Cre-Phex $\Delta f l o x / y$ mice) and conditional osteocalcin-promoted (OC-promoted) Phex inactivation in osteoblasts and osteocytes $\left(O C\right.$-Cre-Phex $\left.{ }^{\Delta f l o x} / y\right)$. Serum phosphorus levels in Cre-Phex ${ }^{\Delta f l o x / y}, O C-C r e-P h e x^{\Delta f l o x} / y$, and $h y p$-mice were lower than those in normal mice. Kidney cell membrane phosphate transport in Cre-Phex ${ }^{\Delta f l o x / y}, O C$-Cre-Phex ${ }^{\Delta f l o x / y}$, and hypmice was likewise reduced compared with that in normal mice. Abnormal renal phosphate transport in Cre$P h e x^{\Delta f l o x / y}$ and $O C$-Cre-Phex ${ }^{\Delta f l o x / y}$ mice was associated with increased bone production and serum FGF-23 levels and decreased kidney membrane type IIa sodium phosphate cotransporter protein, as was the case in byp-mice. In addition, Cre-Phex ${ }^{\Delta f l o x / y}, O C-C r e-P h e x^{\Delta f l o x / y}$, and $h y p$-mice manifested comparable osteomalacia. These data provide evidence that aberrant Phex function in osteoblasts and/or osteocytes alone is sufficient to underlie the hyp-mouse phenotype.

\section{Introduction}

X-linked hypophosphatemia (XLH) is the archetypal vitamin Dresistant disease in humans and the most common form of inherited rickets, with an incidence of approximately 1 in 20,000 live births. The disease is characterized by renal phosphate $(\mathrm{Pi})$ wasting with resulting hypophosphatemia, abnormal vitamin $\mathrm{D}$ metabolism, defective bone and cartilage mineralization, dentine defects, and stunted growth (1). Recently, the gene involved in the pathogenesis of XLH was identified by positional cloning (2-4) and designated as PHEX (the phosphate-regulating gene with homologies to endopeptidases on the $\underline{X}$ chromosome). The PHEX locus was mapped to Xp22.1, and more than 140 loss-of-function PHEX mutations have been reported to date in patients with $\mathrm{XLH}(2)$. The murine homolog of the human disease, the byp-mouse, has a phenotype identical to that evident in patients with $\mathrm{XLH}$ and is due to a large deletion in the $3^{\prime}$ region of the Phex gene (5). These findings suggest that a mutation in the PHEX/Phex gene is responsible for the phenotypic changes in patients with XLH and the hyp-mouse.

The PHEX gene has 22 exons and encodes for a 749-aa glycoprotein, which has homology with members of the M13 membranebound zinc metalloendopeptidase family. Investigation of murine

Nonstandard abbreviations used: Npt2, type IIa sodium Pi cotransporter; OC, osteocalcin; 25(OH)D, 25-hydroxyvitamin D; PHEX, phosphate-regulating gene with homologies to endopeptidases on the $\underline{X}$ chromosome; Pi, phosphate; PTH, parathyroid hormone; XLH, X-linked hypophosphatemia.

Conflict of interest: The authors have declared that no conflict of interest exists. Citation for this article: J. Clin. Invest. 118:722-734 (2008). doi:10.1172/JCI32702. tissues and cell cultures has revealed that Phex is predominantly expressed in bones and teeth $(3,6)$, although Phex mRNA and/or protein have been detected in lung, brain, muscle, gonads, skin, and parathyroid glands. The PHEX/Phex expression in bone is limited to cells of the osteoblast lineage $(6,7)$, osteoblasts, and osteocytes.

The physiological function of the PHEX/Phex gene product and the mechanisms that lead to the biochemical and skeletal abnormalities evident in patients with XLH and in the byp-mouse remain ill defined. Since PHEX/Phex codes for a membrane-bound enzyme, several groups have postulated that PHEX/Phex activates or degrades a putative Pi- and bone mineralization-regulating factor(s), phosphatonin or minhibin, which are involved in the regulation of $\mathrm{Pi}$ and mineralization processes $(1,8-11)$. Studies in patients with XLH and the byp-mouse, as well as in a wide variety of other Pi wasting disorders, have identified several candidate proteins as the phosphatonin(s) or minhibin(s), including FGF-23 $(12,13)$, sFRP4 $(14,15), \operatorname{MEPE}(16,17)$, and FGF-7 (18). Since abnormal production or circulating levels of several of these factors have been identified in patients with XLH and in byp-mice, it remains unknown whether a single phosphatonin is responsible for the physiological abnormalities of the disease or a family of proteins works cooperatively to create the HYP phenotype.

Despite the significant advances made in understanding the pathogenesis of XLH, further progress has been limited by unsuccessful efforts to completely rescue the HYP phenotype and determine the physiologically relevant site for the PHEX mutation. In attempts to determine whether abnormal PHEX/Phex expression in bone cells alone is the determining abnormality underlying the pathogenesis 


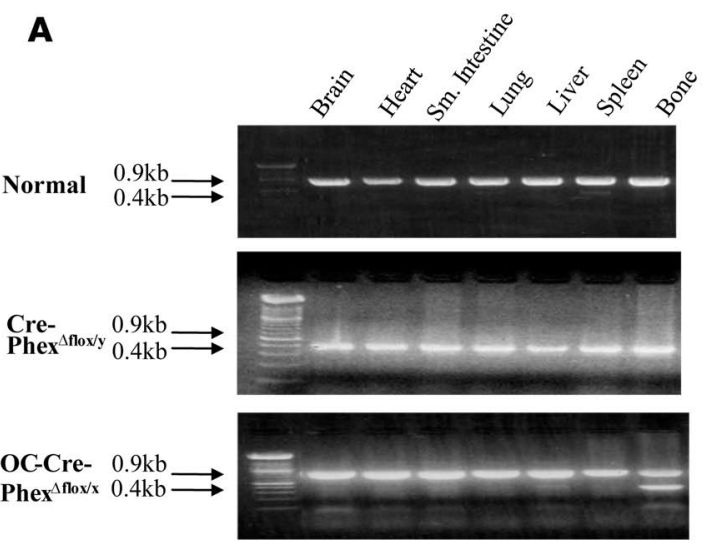

B

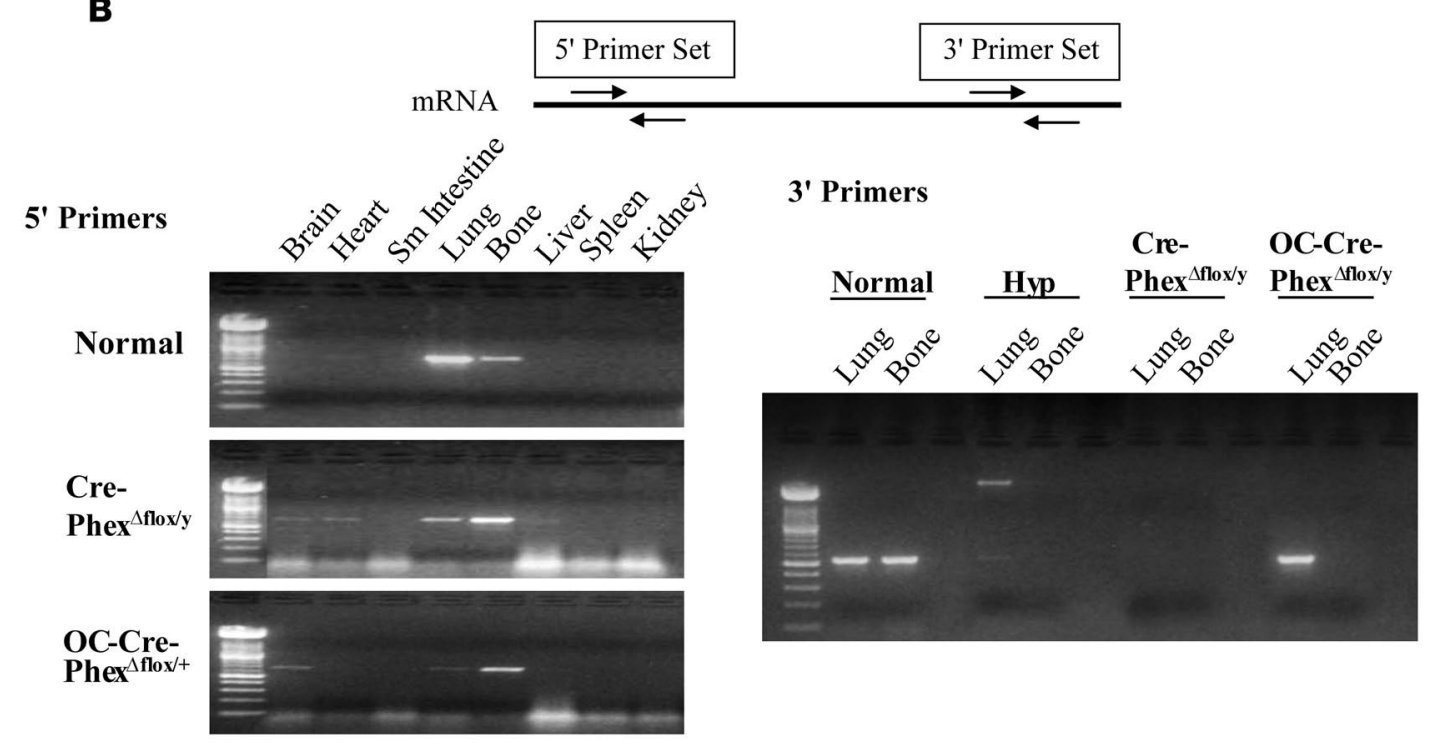

Figure 1

Phex DNA genotyping and mRNA expression in knockout mice. (A) DNA genotyping showed that Phex DNA (0.9 kb) was identified in every tested tissue of normal mice. In contrast, a truncated gene of $0.4 \mathrm{~kb}$ was present in all tissues of the global knockout (Cre-Phex $\left.{ }^{\Delta t l o x / y}\right)$ mice, while the targeted knockout mice (OC-Cre-Phex $\left.{ }^{\Delta t l o x / y}\right)$ had the truncated gene only in bone (a female heterozygous mouse was used in these studies to assure conditions were appropriate for gene expression of the $0.9-\mathrm{kb}$ band). (B) Phex mRNA expression. Two sets of primers were used to detect the Phex expression upstream and downstream of exon 17 . When using $5^{\prime}$ upstream primers, the Phex gene was mainly expressed in lung and bone tissues in the normal and knockout models. However, when $3^{\prime}$ primers were used, the expression pattern changed, and while Phex mRNA expression was absent from lung and bone of Cre-Phex ${ }^{\Delta t / o x / y}$ mice, the OC-Cre-Phex ${ }^{\Delta t / o x / y}$ mice lacked Phex mRNA only in bone tissue.

of XLH, several investigators have used osteoblast/osteocyte-targeted overexpression of Phex in order to normalize osteoblast mineralization, in vitro, and rescue the HYP phenotype in vivo $(19,20)$. Surprisingly, however, these studies documented that restoration of Phex expression and enzymatic activity to immortalized hyp-mouse osteoblasts, by retrovirus-mediated transduction, does not restore their capacity to mineralize extracellular matrix in vitro, under conditions supporting normal mineralization. Moreover, in complementary studies, Liu et al. (19) and Bai et al. (20) found that transgenic byp-mice maintained characteristic hypophosphatemia and abnormal vitamin D metabolism, as well as histological evidence of osteomalacia, despite expressing abundant Phex mRNA and enzyme activity in mature osteoblasts and osteocytes, under the control of the bone-specific promoters osteocalcin (OC) and ColA1 (2.3 kb). These findings suggest that expression of Phex at sites other than bone is responsible for the HYP phenotype. However, similar studies performed with transgenic mice in which Phex overexpression was under the regulation of the ubiquitous human $\beta$-actin promoter likewise failed to normalize the Pi homeostasis (21).

To definitively explore this apparent paradox, we sought to determine whether conditional inactivation of Phex in osteoblasts and osteocytes generates a biochemical phenotype similar to that in mice with a global Phex knockout and comparable to that in hypmice. In order to accomplish this goal, we generated mouse lines with global and targeted deletion of exon 17 from the Phex gene, which codes a portion of the protein crucial for bioactivity. We compared biochemistries and bone histology in the global and targeted Phex-knockout mice with those in hyp- and normal mice.

\section{Results}

Phex expression in knockout mice. In order to determine the presence or absence of exon 17 in the Phex gene of the knockout models, 


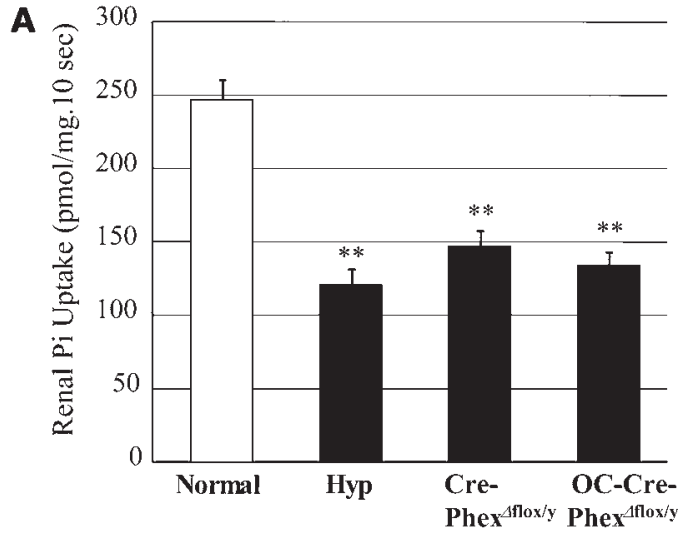

B

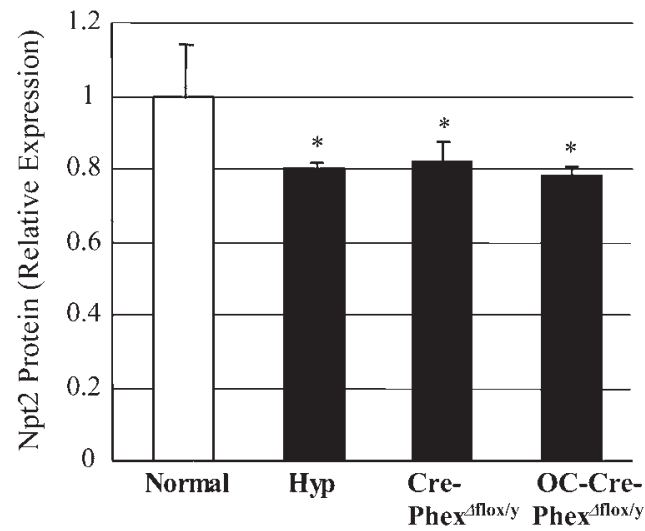

DNA was extracted from various tissues and PCR amplification performed. Figure 1A illustrates that in normal mice, the Phex gene is identified by a $0.9-\mathrm{kb}$ band, which was present in every tested tissue. In contrast, in global Cre-Phex ${ }^{\Delta f l o x / y}$ knockout mice, the successful deletion of exon 17 in all tissues was reflected by the ubiquitous presence of a truncated Phex gene of only 0.4 $\mathrm{kb}$, while in the targeted OC-Cre-Phex ${ }^{\Delta f l o x / y}$ knockout mouse, the truncated gene was present only in bone (data shown here for a heterozygous female mouse).

To confirm that the truncated gene resulted in the absence of Phex expression, we amplified the RNA isolated from the various tissues by RT-PCR (Figure 1B). When a 5'-primer set (Phex, GenBank accession number NM_011077, forward [1,400-1,419 bp], 5'-CCGAACCAGTGAGGCTATGT-3'; and reverse [1,921-1,902 bp], 5'-TTCCTTTTTGTCCCTGCATC-3') was used, detecting expression around exon 9, the Phex mRNA pattern in the knockout models was identical to that in normal mice, and expression was detected in lung and bone samples in all 3 mouse models. In contrast, using a $3^{\prime}$-primer set (forward [2,334-2,253 bp], 5'TGGTGGTCTGTGGAATCAGA-3'; and reverse [2,802-2,784 bp], 5'-GAAGGCAGAAACCAGCACTC-3'), which detected Phex mRNA expression downstream of exon 17, RT-PCR of the RNA samples from lung and bone showed that Phex mRNA was expressed in normal lung and bone tissues but was absent in both tissues in Cre-Phex ${ }^{\Delta f l o x / y}$ knockout mice, as in byp-mice, but only in the bone of OC-Cre-Phex ${ }^{\Delta f l o x / y}$ mice.

These data indicate that removal of exon 17 from the Phex gene diminished expression of Phex mRNA in all tissues of the Cre$P h e x^{\Delta f l o x / y}$ knockout mice but only in the bone of OC-Cre-Phex ${ }^{\Delta f l o x / y}$

\section{Figure 2}

$\mathrm{Pi}$ transport across renal brush border membrane and Npt2 protein content in the kidney. (A) Both knockout mice exhibited decreased renal $\mathrm{Pi}$ transport in renal brush border membranes, similar to that in hyp-mice, when compared with the normal controls. (B) Western blotting showed comparable decreases in the renal tubular Npt2 cotransporter in both knockout and hyp-mice when compared with the normal controls. ${ }^{*} P<0.05,{ }^{* \star} P<0.01$ compared with normal mice.

knockout mice. These mouse models, which carried the mutant Phex gene in a tissue-specific fashion, allowed investigation of the requisite abnormality necessary to express the HYP phenotype.

Biochemistries in the knockout mice. We examined the serum Pi and $\mathrm{Ca}^{2+}$ levels in Cre-Phex ${ }^{\Delta f l o x / y}$ and OC-Cre-Phex ${ }^{\Delta f l o x / y}$ mice, as well as in normal and hyp-mice, at 8 weeks of age. Both Cre-Phex ${ }^{\Delta f l o x / y}$ $(3.29 \pm 0.22 \mathrm{mg} / \mathrm{dl})$ and OC-Cre-Phex ${ }^{\Delta f l o x} / y(3.52 \pm 0.17 \mathrm{mg} / \mathrm{dl})$ mice had significantly decreased $(P<0.001)$ serum Pi levels compared with those of normal mice $(7.05 \pm 0.35 \mathrm{mg} / \mathrm{dl})$. The decreased Pi levels were comparable to the significantly decreased $(P<0.001)$ concentration manifest in byp-mice $(3.76 \pm 0.17 \mathrm{mg} / \mathrm{dl})$.

Similarly, the serum $\mathrm{Ca}^{2+}$ levels in Cre-Phex ${ }^{\Delta f l o x / y}(8.51 \pm 0.18$ $\mathrm{mg} / \mathrm{dl})$ and $O C$-Cre-Phex ${ }^{\Delta f l o x / y}(8.48 \pm 0.16 \mathrm{mg} / \mathrm{dl})$ mice were no different from those of byp-mice $(8.35 \pm 0.12 \mathrm{mg} / \mathrm{dl})$. However, hyp-mice and the knockout models maintained serum calcium levels that were not significantly different from those in normal mice $(8.72 \pm 0.25 \mathrm{mg} / \mathrm{dl})$.

Renal Pi transport in the knockout mice. To determine whether the hypophosphatemia in the knockout mice was due to abnormal renal Pi handling, we examined brush border membrane Pi transport (Figure 2A). The Cre-Phex ${ }^{\Delta f l o x / y}(146.7 \pm 10.9 \mathrm{pmol} / \mathrm{mg} / 10 \mathrm{~s})$ and OC-CrePhex ${ }^{\Delta f l o x / y}(134.3 \pm 8.6 \mathrm{pmol} / \mathrm{mg} / 10 \mathrm{~s})$ mice exhibited significantly decreased $(P<0.01)$ Pi transport compared with that in normal mice $(246.7 \pm 13.8 \mathrm{pmol} / \mathrm{mg} / 10 \mathrm{~s})$ but similar to that characteristically observed in byp-mice $(120.7 \pm 10.9 \mathrm{pmol} / \mathrm{mg} / 10 \mathrm{~s})$.

Consistent with these observations, analysis of Western blots revealed that the aberrant Pi transport in Cre-Phex ${ }^{\Delta f l o x / y}$ and OC-CrePhe $x^{\Delta f l o x / y}$ mice, like that in the byp-mice, was due to a significant decrease $(P<0.05)$ in renal tubular type IIa sodium Pi cotransporter $(\mathrm{Npt} 2)$ protein expression, compared with that in normal mice (Figure 2B). Indeed, in the knockout and byp-mice, a comparable approximately $20 \%$ decrement in the abundance of the Npt2 protein was observed.

Vitamin D metabolism in the knockout mice. In previous studies, we established that byp-mice manifest aberrant regulation of vitamin D metabolism, resulting from a unique abnormality in 25-hydroxyvitamin D-1 $\alpha$-hydroxylase [25(OH)D-1 $\alpha$-hydroxylase] translational activity (22). To ascertain whether Phex deletion resulted in a similar defect, we investigated $\mathrm{Pi}$ - and parathyroid hormone-mediated (PTH-mediated) vitamin D metabolism in both knockout mice. At the time of study, the knockout mice and byp-mice had comparable hypophosphatemia, as noted above. However, despite the stimulatory effects of hypophosphatemia on renal $25(\mathrm{OH}) \mathrm{D}-1 \alpha$-hydroxylase activity, Cre-Phex ${ }^{\Delta f l o x / y}$ and OC-Cre-Phex ${ }^{\Delta f l o x / y}$ mice, similar to bypmice, displayed no significant enhancement of enzyme function (Figure 3A). Nevertheless, each of these animal models displayed a 2.0 -fold increment in $25(\mathrm{OH}) \mathrm{D}$ - $1 \alpha$-hydroxylase mRNA transcripts (Figure 3B). However, the Cre-Phex ${ }^{\Delta f l o x / y}$ and OC-Cre-Phex $x^{\Delta f l o x / y}$ mice, like byp-mice, manifested no stimulation of $25(\mathrm{OH}) \mathrm{D}-1 \alpha$-hydroxylase protein content, consistent with a translational abnormality in vitamin D metabolism (Figure 3C). 


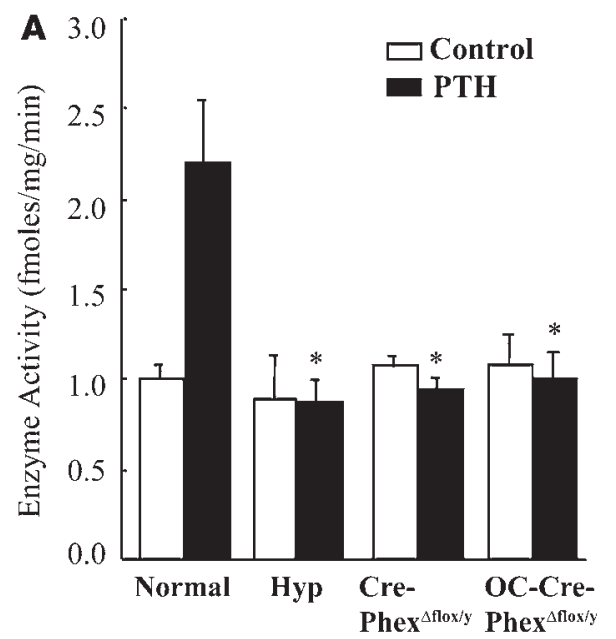

B

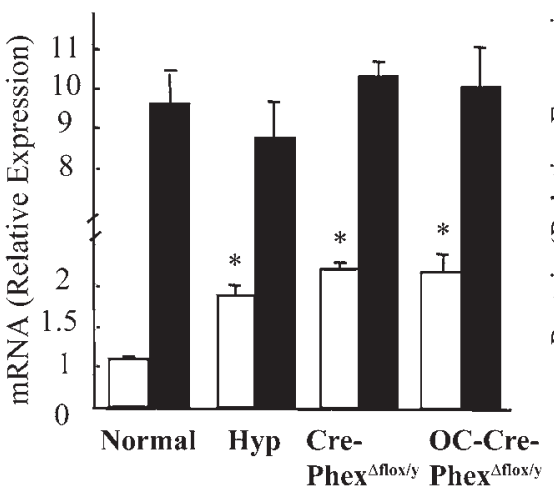

C

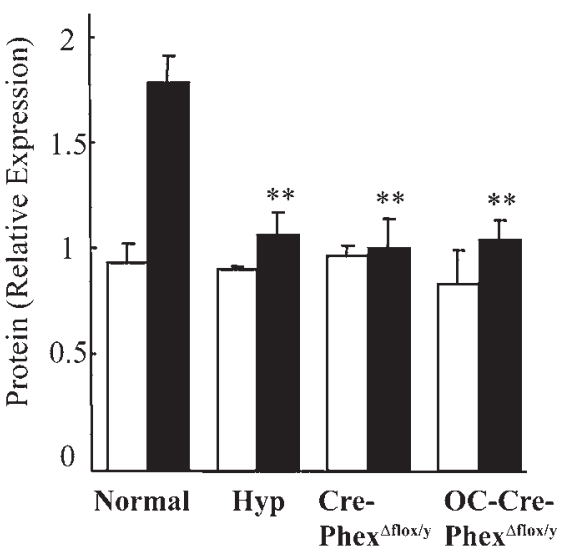

Figure 3

Effects of Pi and PTH $(300 \mu \mathrm{g} / \mathrm{kg} / \mathrm{d})$ stimulation on $25(\mathrm{OH}) \mathrm{D}-1 \alpha$-hydroxylase mRNA, protein, and enzyme activity in knockout mice. (A) In the baseline state, hyp-mice and the knockouts failed to exhibit increased $25(\mathrm{OH}) \mathrm{D}-1 \alpha$-hydroxylase activity despite significant hypophosphatemia. PTH significantly increased enzyme activity only in the normal mice and had no effect on 25(OH)D-1 $\alpha$-hydroxylase function in hyp-mice or both knockout mice compared with the corresponding normals. (B) In response to the prevailing hypophosphatemia in the baseline state, the hypmice and both knockouts manifested increased mRNA transcripts. In response to PTH stimulation, the hyp-mice and both knockouts exhibited enhancement of the mRNA transcripts similar to that observed in normal mice. (C) The increased mRNA in the hyp-and the knockout mice in the baseline state and following PTH stimulation did not result in enhanced translation of the $25(\mathrm{OH}) \mathrm{D}-1 \alpha$-hydroxylase protein when compared with the corresponding normal mice. ${ }^{\star} P<0.05,{ }^{\star *} P<0.01$ compared with corresponding normal mice.

To confirm the dissociation between mRNA expression and renal $25(\mathrm{OH}) \mathrm{D}-1 \alpha$-hydroxylase activity in the knockout mice and further establish that the defect was similar to that in byp-mice, we examined the effects of PTH stimulation on $25(\mathrm{OH}) \mathrm{D}-1 \alpha$-hydroxylase activity in the various animal models. PTH stimulation of byp-mice resulted in a 10 -fold elevation of $25(\mathrm{OH}) \mathrm{D}-1 \alpha$-hydroxylase mRNA, similar to the effects of stimulation in normal mice and to that evidenced in both Cre-Phex ${ }^{\Delta f l o x / y}$ and OC-Cre-Phex ${ }^{\Delta f l o x / y}$ mice (Figure 3B). However, the increased mRNA in the byp-mice and the knockout mice did not result in enhanced translation of the $25(\mathrm{OH}) \mathrm{D}-1 \alpha$ hydroxylase protein, while normal mice, as expected, did manifest increased translational activity (Figure 3C). Consistent with these observations, PTH increased enzyme activity only in the normal mice and had no effect on $25(\mathrm{OH}) \mathrm{D}-1 \alpha$-hydroxylase activity in bypmice or the Cre-Phex ${ }^{\Delta f l o x / y}$ and OC-Cre-Phex ${ }^{\Delta f l o x / y}$ mice (Figure 3A).

Bone structure and histomorphology in the knockout mice. Radiographic evaluation of long bones from Cre-Phex ${ }^{\Delta f l o x} / y$ and OC-Cre-Phex ${ }^{\Delta f l o x / y}$ mice revealed that length was decreased compared with that in normal mice but was similar to that in byp-mice (Figure 4A). Indeed, measurements of femur length in normal and byp-mice, as well as the Cre-Phex $x^{\Delta f l o x / y}$ and OC-Cre-Phex ${ }^{\Delta f l o x / y}$ mice, confirmed that the femur length in the knockout models was significantly $(P<0.001)$ less than that in normals, but no different from that in byp-mice (Figure 4B).

In addition, both knockout mice, like byp-mice, exhibited profound osteomalacia (Figure 5) characterized by hyperosteoidosis, as evidenced by histological examination of Goldner-stained sections (Figure 5A), which revealed an apparent excess of unmineralized osteoid. The mineralization defect was confirmed in Cre-Phex ${ }^{\Delta f l o x / y}$ and $O C$-Cre-Phex ${ }^{\Delta f l o x / y}$ mice and hyp-mice by the complete absence of distinct double-fluorescent labels in the respective bone sections from these animals (Figure 5B). Indeed, only diffuse, nonquantifiable label was present beneath widened osteoid seams. Most impor- tantly, quantitative histomorphometric evaluation of the Goldnerstained bone sections revealed that the severity of the osteomalacia was equal in the knockout models and the byp-mice (Figure 5C).

Further, confocal microscopic examination of bone sections from procion red-treated mice revealed that in normal mice, the osteocyte lacunae were highly organized and regularly spaced in linear arrays, whereas the osteocyte lacunae in the bone from Cre-Phex ${ }^{\Delta f l o x / y}$ and OC-Cre-Phex ${ }^{\Delta f l o x / y}$ mice, as well as those from hypmouse bone, were much larger and randomly oriented (Figure 6A). The marked abnormalities in the distribution and organization of the osteocyte-lacunocanalicular system in the knockout and byp-mice were further documented with acid-etched scanning electron microscopic images (Figure 6B). Indeed, the inner lacunocanalicular wall was smooth in the bone sections from normal mice, but the wall was buckled and enlarged in the sections from Cre-Phex ${ }^{\Delta f l o x} / y$, OC-Cre-Phex ${ }^{\Delta f l o x / y}$, and hyp-mice (Figure 6C). These results established that loss of Phex function in all tissues or in bone (osteoblasts/osteocytes) alone created a biochemical and bone phenotype indistinguishable from that in byp mice.

Serum levels and production of phosphatonins in the knockout mice. To establish whether the pathophysiological abnormalities in the knockout mice were due to a cascade of events similar to that observed in byp-mice, we explored whether Cre-Phex ${ }^{\Delta f l o x / y}$ and OC-Cre$P h e x^{\Delta f l o x / y}$ mice, like the hyp-mice, exhibit a Phex-dependent increase in the circulating levels of the phosphatonins, as well as increased phosphatonin production. Serum FGF-23 levels were increased dramatically $(P<0.001)$ in Cre-Phex ${ }^{\Delta f l o x / y}$ and OC-Cre-Phex ${ }^{\Delta f l o x / y}$ mice to levels comparable to those in byp-mice (Figure 7). Consistent with these findings, FGF-23 mRNA measurements in bone revealed a significant increase $(P<0.01)$ in Cre-Phex $x^{\Delta f l o x / y}$ and OC-Cre-Phex ${ }^{\Delta f l o x / y}$ mice, equivalent to that observed in the byp-mice (Figure 8).

In contrast, serum MEPE-ASARM-peptide $(P<0.001)$ and sFRP-4 levels $(P<0.05)$ were significantly elevated in Cre-Phex $x^{\Delta f l o x / y}$ mice, 

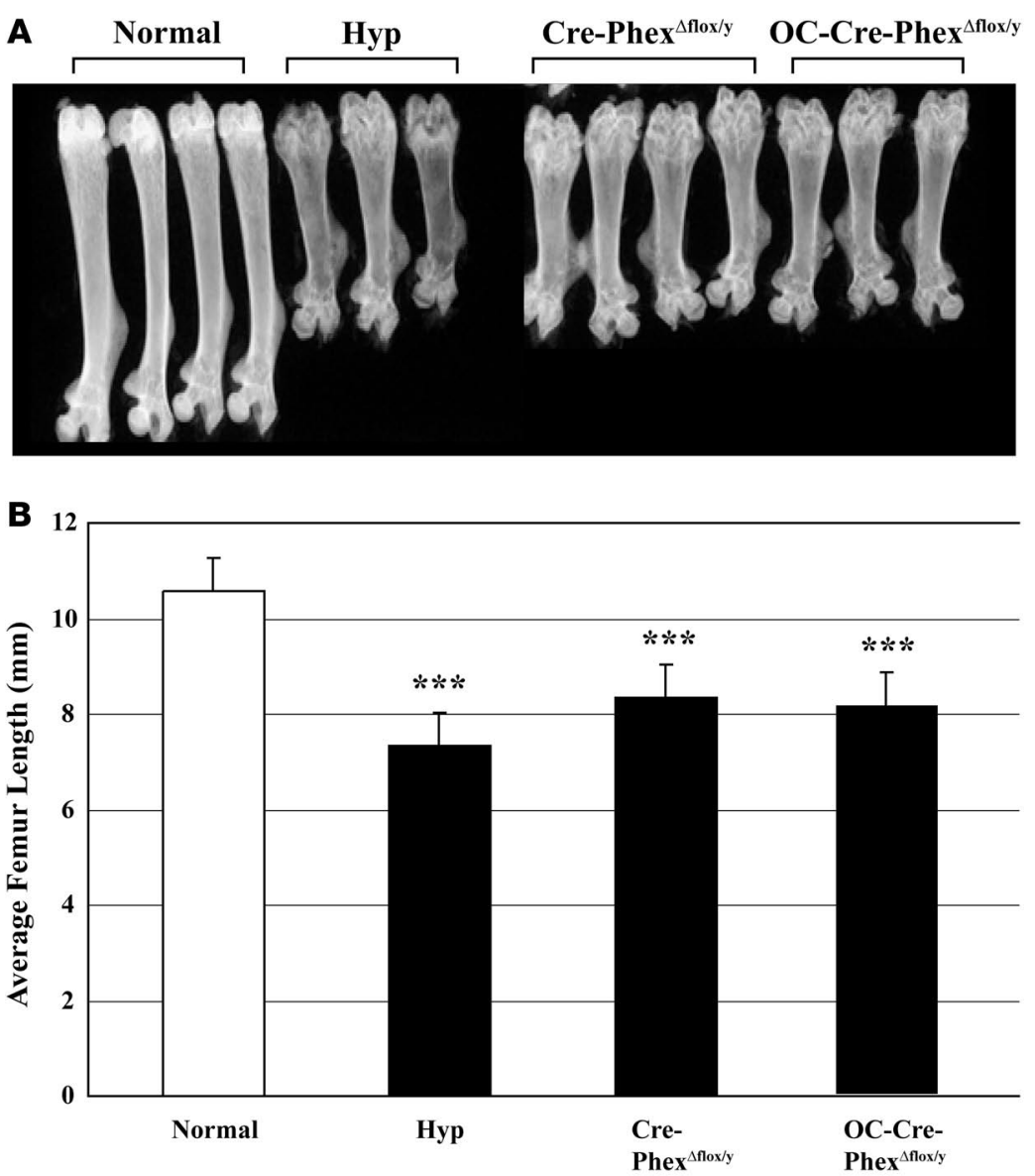

\section{Figure 4}

Femur length in normal, hyp-, and knockout mice. (A) High-resolution radiographics revealed that CrePhex ${ }^{\Delta f l o x / y}$ and OC-Cre-Phex ${ }^{\Delta f l o x / y}$ mice had shortened femurs comparable to those in hyp-mice. (B) The bar graph presents the average femur length in the normal, hyp-, Cre-Phex ${ }^{\Delta f l o x / y}$, and OC-Cre-Phex ${ }^{\Delta f l o x / y}$ mice. Compared with normal mice, the hyp-, Cre-Phex ${ }^{\Delta f l o x / y}$, and OC-Cre-Phex ${ }^{\Delta f l o x / y}$ mice had significantly decreased femur length. Measurements in at least 6 femurs in each group revealed a significant decrease (averaging $2.5 \mathrm{~mm}$ ) in femur length in hyp-, Cre-Phex ${ }^{\Delta f l o x / y}$, and $O C$-Cre-Phex ${ }^{\Delta t / o x / y}$ compared with normal mice. ${ }^{* \star *} P<0.001$ compared with normal mice. as in the byp-mice, but not in OC-Cre-Phex ${ }^{\Delta f l o x / y}$ mice (Figure 7). Not surprisingly, real-time PCR studies revealed a significant increase in MEPE $(P<0.01)$ and sFRP-4 $(P<0.05)$ expression in bone samples only of Cre-Phex $x^{\Delta f l o x / y}$ mice to levels comparable to those in byp-mice (Figure 8).

\section{Discussion}

Although many investigators suspect that mutated Phex and a lack of Phex activity in the hyp-mouse osteoblast is directly responsible for impaired mineralization and abnormal Pi homeostasis in the mutants, multiple strategies, including bone marrow transplantation (23) and targeted overexpression of Phex in osteoblasts $(19,20)$, have failed to substantiate this concept. However, it is uncertain whether such disparate observations resulted because: (a) physiologically relevant Phex expression occurs in cells other than osteoblasts; or (b) the experimental procedures employed had innate limitations, such as errant temporal or cellular expression of Phex in transgenic animals. Regardless, the need to discern with certainty the cell type(s) in which Phex expression is essential to regulate the phenotypic expression of XLH and the extent of the phenotype due directly and secondarily to a specific phosphatonin(s) produced by the osteoblast/osteocyte remains of substantial importance. Indeed, development of novel therapeutic strategies for the disease and identification of the putative phosphatonin(s) central to the pathophysiology of the disease have been hampered by the absence of such information. The Cre-loxP genetic strategy has been developed that enables inactivation of mouse genes in a tissue-specific (or cell-specific) fashion (24). The opportunity to employ the Cre-loxP strategy to knock out Phex in osteoblasts and osteocytes and determine with certainty the physiologically relevant site for gene expression has been facilitated by the recent development of FVB-N mice expressing Cre recombinase under the control of the osteoblast/osteocyte-specific promoter OC. Indeed, Zhang et al. (25) have found that in transgenic mice, OC-Cre mRNA is expressed at high levels in calvariae and vertebrae and is undetectable in other tissues, including brain, heart, kidney, liver, skeletal muscle, spleen, and stomach. Further, they demonstrated that the level of Cre expression in the transgenic FVB-N mice is sufficient for high-level recombination; indeed, crossing the $\mathrm{OC}-\mathrm{Cre}^{+/-}$mice with a mouse carrying a floxed LacZ gene upstream of a human alkaline phosphatase gene revealed a greater than $90 \%$ recombination at the LacZ locus, as evidenced by the appearance of alkaline phosphatase-positive osteoblasts and osteocytes. More recently, the OC-Cre transgene has been backcrossed onto the C57BL/6J background for more than 7 generations, and subsequent crossing of the OC-Cre ${ }^{+/-}$mice, maintained on this background, again demonstrated that the level of Cre expression results in high-level recombination (T.L. Clemens, unpublished observations).

In the current studies, we used traditional techniques to successfully create C57BL/6J mice with a floxed Phex gene, in which exon 17 was targeted for deletion. Using EIIa-Cre mice to remove the Neo cassette from floxed mice, we created global exon 17-knockout mice Cre-Phex ${ }^{\Delta f l o x / y}$ for controls in our studies. Further, employing the C57BL/6J OC-Cre mice discussed above, we produced mice with 
A
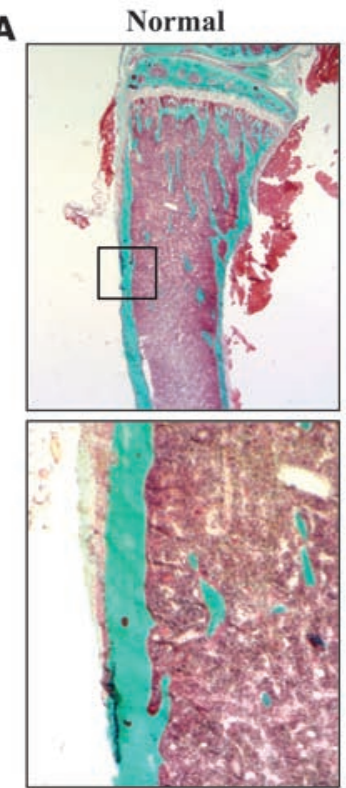

$\mathbf{B}$

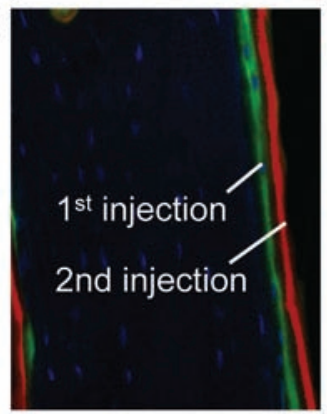

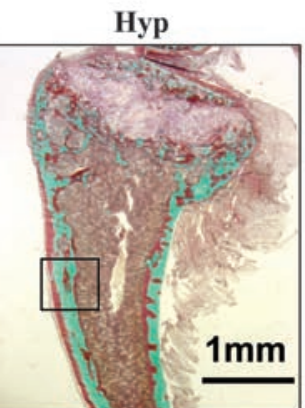
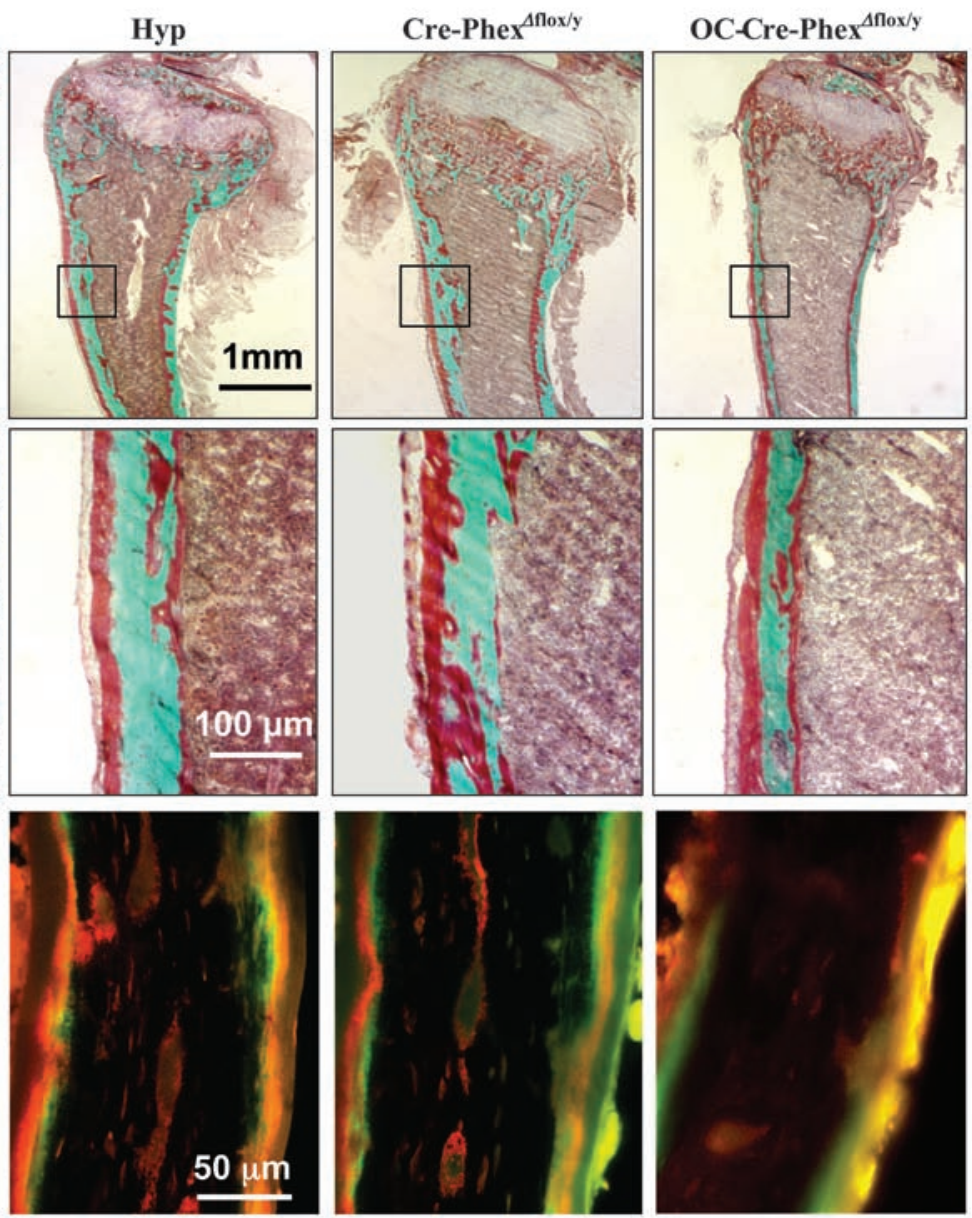

C
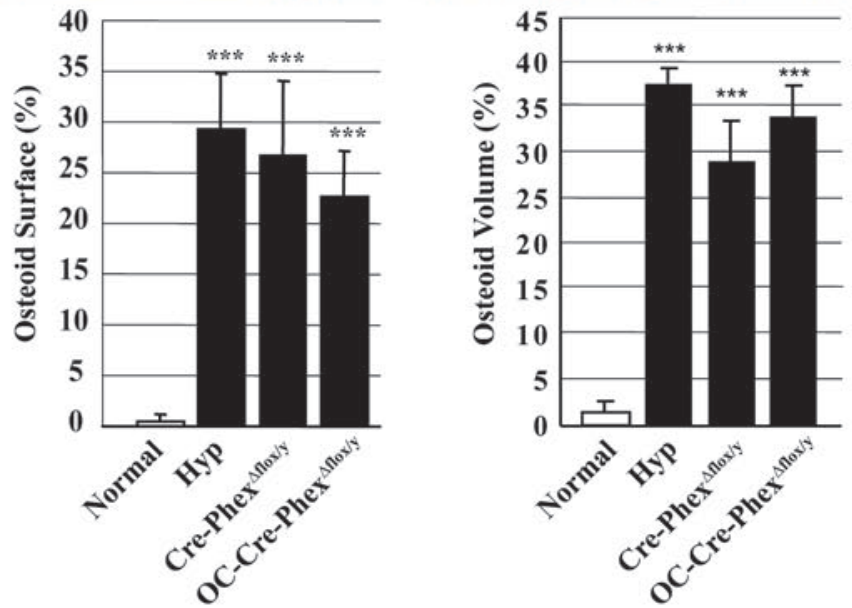

Figure 5

Bone histomorphology in normal, hyp-, Cre-Phex ${ }^{\Delta f l o x / y}$, and OC-Cre-Phex ${ }^{\Delta f l o x / y}$ mice. (A) Goldner-stained sections of cortical bone reveal at low magnification an apparent increase in unmineralized osteoid (red-brown colored) in the hyp-, Cre-Phex ${ }^{\Delta f l o x / y}$, and OC-Cre-Phex ${ }^{\Delta f l o x / y}$ mice, compared with that in normals. At higher magnification, the evident increased unmineralized osteoid in the cortical bone specimens from the hyp-, Cre-Phex ${ }^{\Delta t l o x / y}$, and OC-Cre-Phex $\Delta f / 0 x / y$ mice appears comparable in magnitude. (B) The double-labeled bone specimens, viewed under fluorescent light, show normal mineralization in the normal mice, manifested by distinct dual labels deposited beneath narrow osteoid seams. In contrast, the bone sections from the hyp-, Cre-Phex ${ }^{\Delta f l o x / y}$, and OC-Cre-Phex $x^{\Delta f l o x / y}$ mice have diffuse smudged fluorescent labels under widened osteoid seams, indicating a disorderly deposition of mineral characteristic of osteomalacia. The diffuse patchy double labels were too indistinct to permit quantitative assessment of the abnormal mineralization dynamics. (C) Quantitative histological exam of the Goldner-stained sections from a minimum of 6 animals in each group revealed significantly increased osteoid surface and osteoid volume in the hyp-, Cre-Phex $x^{\Delta t l o x / y}$, and $O C$-Cre-Phex ${ }^{\Delta f l o x / y}$ mice, as indicated by the asterisks denoting statistically significant values $\left({ }^{* * *} P<0.001\right)$. In contrast, there was no significant difference in these values in the knockout models and the hyp-mice (denoted by the black columns), again providing evidence that the osteomalacia was of comparable magnitude in these animal models. 


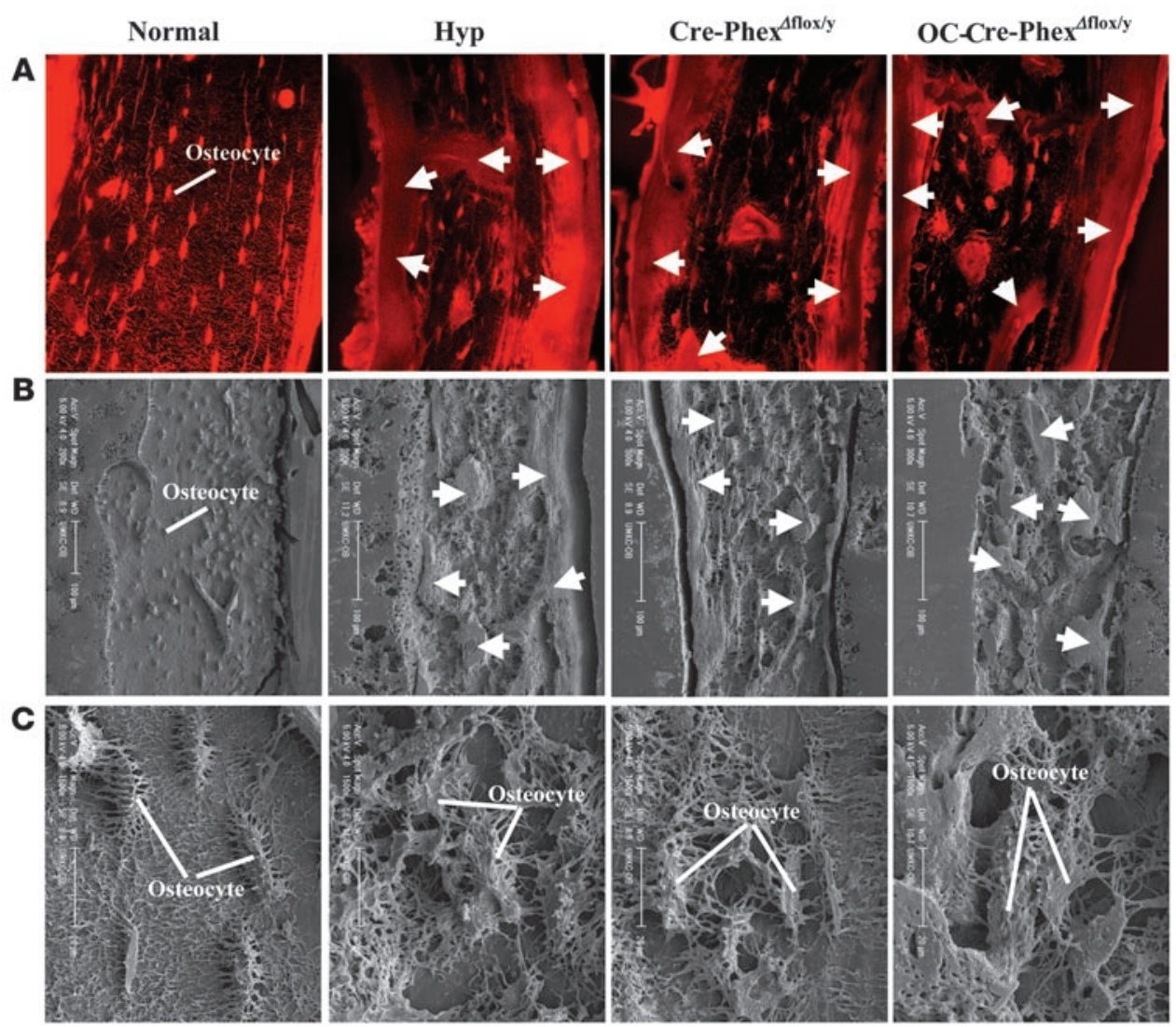

Figure 6

Porcine red staining and scanning electron microscopy with acid itch images of bone sections. (A) The porcine red stain highlights the abundant and well-ordered osteocytes in normal mice and the excessive osteoid (arrows) observed in the hyp-, Cre-Phex $\Delta$ flox/y, and OC-Cre-Phex ${ }^{\Delta f l o x / y}$ mice. (B) Scanning electron microscopic images at low magnification confirm the abundant, well-ordered osteocytes in the normal mice and the abundant osteoid (arrows) in the hyp-, Cre-Phex ${ }^{\Delta f l o x / y}$, and OC-Cre-Phex ${ }^{\Delta f l o x / y}$ mice. (C) Scanning electron microscopic images at high magnification reveal that normal mice have a well-defined canalicular organization around the osteocytes. In contrast, the canalicular organization of the hyp-, Cre$P h e x^{\Delta f l o x / y}$, and OC-Cre-Phex $x^{\Delta f l o x / y}$ mice was severely and comparably damaged. Original magnification, $\times 60(\mathbf{A}) ; \times 200($ B, left panel); $\times 300$ (B, 3 right panels); $\times 1,500$ (C).

targeted deletion of Phex exon 17 in osteoblasts and osteocytes, OCCre-Phex ${ }^{\Delta f l o x / y}$. Initial investigations of these animal models documented that we had achieved successful deletion of exon 17 in all tissues of the Cre-Phex ${ }^{\Delta f l o x / y}$ knockout, while in the OC-Cre-Phex ${ }^{\Delta f l o x / y}$ knockout, the truncated gene was confined to the osteoblasts and osteocytes in bone. Moreover, measurement of Phex mRNA indicated that the truncated gene resulted in absent Phex expression in multiple tissues of the Cre-Phex ${ }^{\Delta f l o x / y}$ mice but only in the osteoblasts and osteocytes of OC-Cre-Phex ${ }^{\Delta f l o x / y}$ mice (Figure 1).

The availability of these model systems enabled us to determine the physiologically relevant site of the Phex mutation in XLH. Indeed, the targeted knockout models we created established unequivocally that mutation of the Phex gene in osteoblasts and/ or osteocytes alone is sufficient to generate the classical HYP phenotype. In this regard, we discovered that the OC-Cre-Phex ${ }^{\Delta f l o x / y}$ mice exhibited a biochemical phenotype no different from that of the Cre-Phex ${ }^{\Delta f l o x / y}$ mice and indistinguishable from that in the bypmouse. Thus, the OC-Cre-Phex ${ }^{\Delta f l o x / y}$ mice manifest hypophosphatemia secondary to decreased renal Npt2 cotransporter protein and consequent decreased brush border membrane Pi transport, abnor- mutation of the Phex gene in the osteoblast and/or osteocyte is a sufficient abnormality to produce the HYP phenotype. Bone biopsies from the OC-Cre-Phex ${ }^{\Delta f l o x / y}$ mice displayed histomorphological evidence of osteomalacia, marked by abundant osteoid-covered bone surface, widened osteoid seams, and defective mineralization (Figure 5). These changes were indistinguishable from those observed in bone biopsies from the CrePhex $x^{\Delta f l o x / y}$ mice, as well as those from byp-mice. In addition, the canalicular organization of the bone sections from the OC-Cre$P h e x^{\Delta f l o x / y}$ mice was severely disrupted, similar to the disarray evident in the bone of Cre-Phex $\Delta$ flox/y and hyp-mice (Figure 6).

Although the present study establishes that Phex expression in osteoblasts and/or osteocytes initiates the cascade of events responsible for the pathogenesis of XLH, our data are seemingly inconsistent with previous reports that documented the unsuccessful efforts to completely rescue the bone mineralization defect and the complete failure to alter the biochemical phenotype in the hyp-mouse by targeted overexpression of Phex $(19,20)$ These data suggest that extraosseous Phex expression might play an important role in modulating the cascade of events underlying XLH. However, a subsequent study, using transgenic mice expressing PHEX under 
$\underline{H y p}$

Serum FGF-23

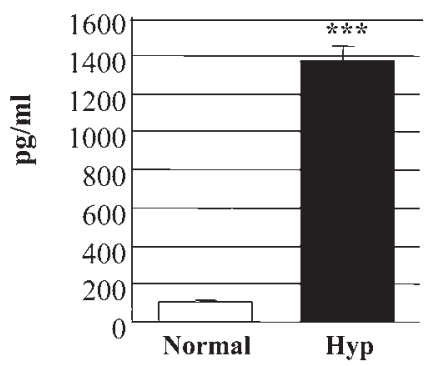

Cre-Phex ${ }^{4 f l o x y}$
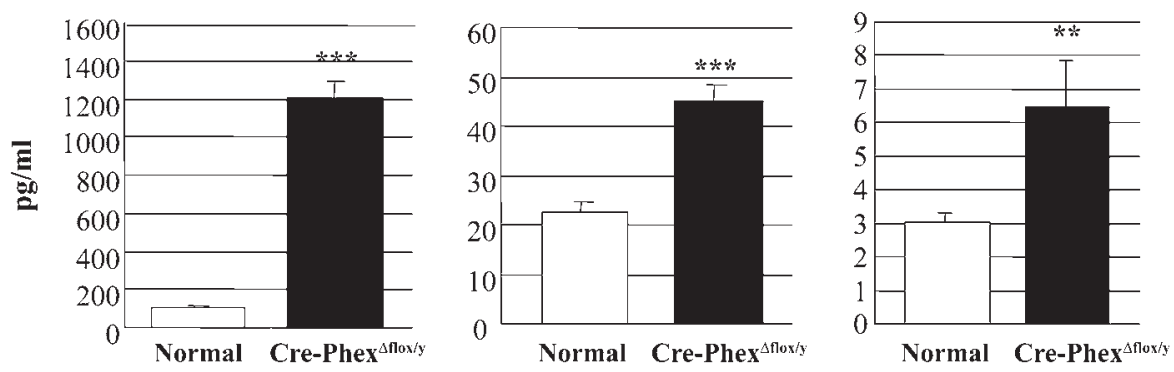

OC-Cre-Phex ${ }^{\text {dlox/y }}$
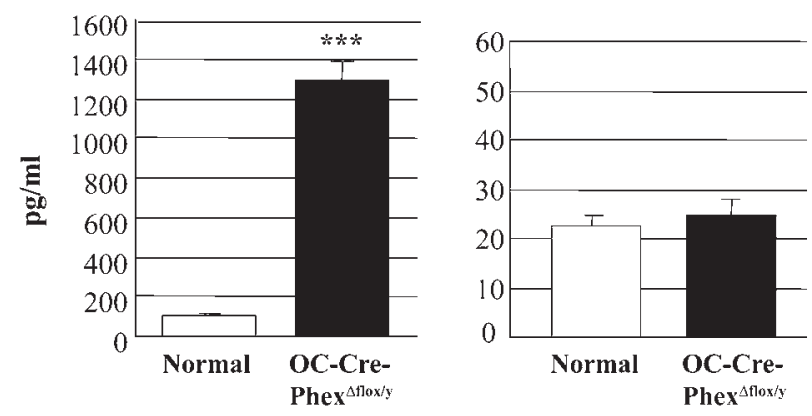

the control of the human $\beta$-actin promoter, which allows more widespread tissue expression of the gene, likewise failed to rescue the bone mineralization defect and the biochemical phenotype in the byp-mouse (21). Although these data seemingly excluded extraosseous Phex expression as a seminal factor in the genesis of $\mathrm{XLH}$, it is possible that the $\beta$-actin-mediated Phex expression was below the level necessary to effect rescue of the phenotype, a possibility acknowledged by Erben et al. (21) in their report. Indeed, since in vivo $\beta$-actin may not be prominently expressed in cells that are mitotically quiescent, their conclusion seems plausible. That the level of expression might have so profound an effect is supported by the observations of Shih et al. (26), who demonstrated that in cultured human osteoblasts, moderate reduction of PHEX mRNA expression by antisense transfection impaired mineralization. Moreover, the conditioned culture medium from the antisense cells reduced Pi uptake in cultured kidney cells (OK cells) (26). In any case, the studies of Erben et al. (21) failed to resolve the issue regarding the possible role of extraosseous Phex expression in the genesis of the HYP phenotype.

Although the level of Phex expression may have influenced the data in the study by Erben et al. (21), the investigations of Phex overexpression in osteoblasts were not similarly impaired. Appropriate
Serum sFRP-4

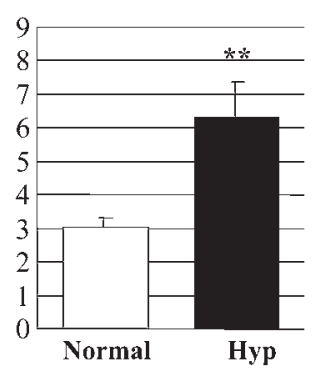

\section{Figure 7}

Serum phosphatonin levels in normal, hyp-, OC-Cre-Phex $\Delta f l o x / y$, and CrePhex ${ }^{\Delta f l o x / y}$ mice. ELISA measurements of serum FGF-23, MEPE, and SFRP-4 levels demonstrated that all 3 phosphatonins were increased in hyp- and Cre$P h e x^{\Delta f l o x / y}$ mice. However, serum FGF-23, but not MEPE or SFRP-4, was increased in OC-Cre-Phex ${ }^{\Delta t l o x / y}$ mice. ${ }^{* *} P<0.01$, ${ }^{* \star *} P<0.001$ compared with corresponding normal mice. controls in these studies revealed that the osteoblasts from the transgenic animal models expressed abundant Phex mRNA and enzyme activity, levels, in fact, greater than those in normal osteoblasts. Thus, if extraosseous production of Phex is not pivotal to the expression of the HYP phenotype, another explanation for the failure to rescue the HYP phenotype by targeted overexpression of the gene in osteoblasts must have prevailed. In this regard, it is possible that the temporal and developmental expression of the osteocalcin- and pro- $\alpha 1$ (I) collagen promoter-driven Phex expression may not mimic the endogenous regulation of Phex. If this is the case, the transgenic animals may have experienced normal PHEX expression later than normal animals or in different osteoblast-related cell subpopulations. In fact, neither promoter is expressed in the preosteoblast, and the osteocalcin promoter appears at least 4 days later than PHEX in normally developing osteoblasts $(19,20)$ Thus, lack of Phex activity early in osteoblast development may result in propagation of immutable osteoblast dysfunction, which contributes to the impairment of mineralization and irreconcilable excess phosphatonin production. Consistent with this hypothesis, later expression of PHEX may not rescue the phenotype.

An alternative explanation for the failure of targeted $P h e x$ expression to rescue the HYP phenotype is the possibility that the mutant Phex protein in hyp-mice represents a dominant negative mutation that blocks the effects of the abundant normal Phex protein in the osteoblasts of the transgenic mice. In support of this possibility, a previous report revealed the accumulation of Phex mutant proteins in the endoplasmic reticulum of osteoblasts (7). However, Liu et al. (19) demonstrated that the $3^{\prime}$ deletion Phex mutant did not interfere with the mineralization of normal osteoblasts in vitro, nor did it disrupt the enzymatic activity of wild-type Phex in vitro. Therefore, the previously reported studies neither established whether extraosseous Phex expression is pivotal to the manifestation of the HYP phenotype nor excluded that mutation of Phex in the osteoblast is the requisite defect responsible for the abnormal mineralization and biochemical abnormalities characteristic of $\mathrm{XLH}$. Hence, these studies provided no data that are inconsistent with our observations. 
$\underline{H y p}$

FGF-23 mRNA

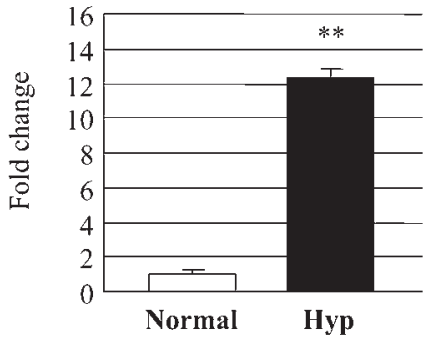

Cre-Phex ${ }^{4 f l o x y}$

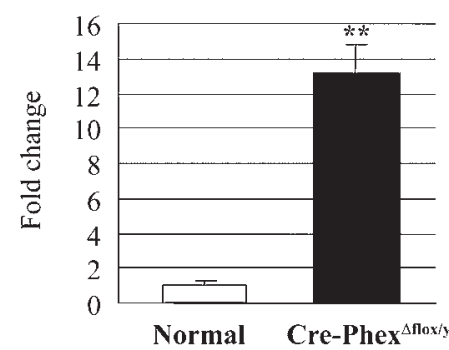

$\underline{\text { OC-Cre-Phex }}{ }^{A f l o x / y}$
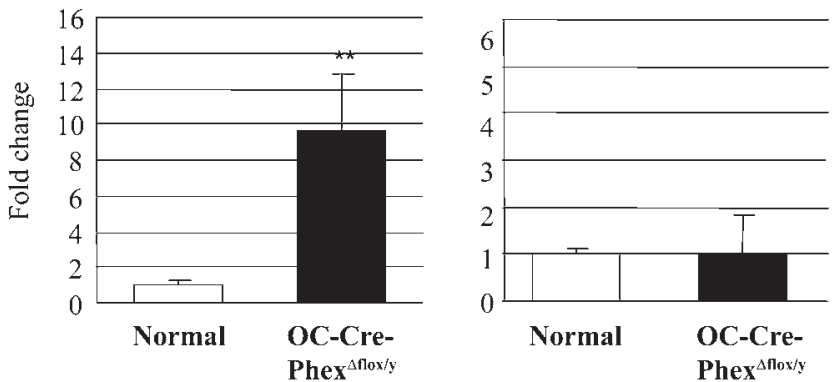

Several previous studies, however, are consistent with our documentation that the osteoblast and/or the osteocyte are the site of the physiologically relevant Phex mutation in hyp-mice. Since endopeptidases such as Phex have substrates that are coexpressed in an organ/cell type-specific fashion, physiologically relevant PHEX/Phex substrate is likely produced in osteoblasts or osteocytes, if these cells are the site of predominant PHEX/Phex mutation. Hence, the osteoblast and osteocyte production of biological products with activity that can modulate such functions as bone mineralization and renal Pi transport would be anticipated. In this regard, several reports indicate that cultured byp-mouse osteoblasts secrete a factor(s) that not only inhibits renal Pi transport $(27,28)$ but impairs bone mineralization $(9,29)$. Thus, these data support the possibility that the osteoblast and/or the osteocyte are the relevant site(s) of Phex mutation, a conclusion reaffirmed and established by our studies.

Although our observations provide compelling evidence that aberrant PHEX/Phex function in osteoblasts and/or osteocytes underlies the characteristic biochemical and pathological phenotype in byp-mice and likely XLH, a surprising discordance between the biochemical phenotype in the targeted OC-Cre-Phex ${ }^{\Delta f l o x / y}$ knockout mice and that in both the global Cre-Phex ${ }^{\Delta f l o x / y}$ knockout and hyp-mice became apparent with further study. Previous stud-
SFRP-4 mRNA

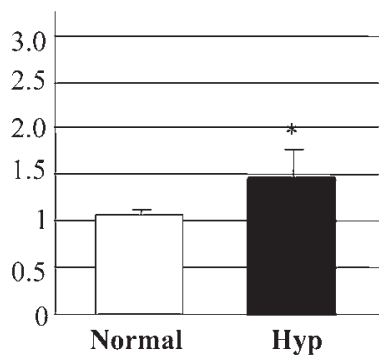

\section{Figure 8}

Real-time PCR results demonstrated the phosphatonin mRNA expression in normal, hyp-, OCCre-Phex ${ }^{\Delta f l o x / y}$, and Cre-Phex $x^{\Delta f l o x / y}$ mouse bone samples. Production of FGF-23, MEPE, and SFRP-4 was increased in hyp- and Cre$P h e x^{\Delta f l o x / y}$ mice. However, only FGF-23 production was increased in OC-Cre-Phex $x^{\Delta l o x / y}$ mice. ${ }^{*} P<0.05,{ }^{* *} P<0.01$ compared with corresponding normal mice.

ies have implicated the phosphatonins as critical factors in the pathogenesis of XLH. Such investigations have identified that the production rate and/or the circulating level of the phosphatonins FGF-23, MEPE, and SFRP-4 are increased in affected humans and/or the byp-mouse. In our studies, however, we found that the OC-Cre-Phex $\Delta$ flox/y mice had only an increased osseous production rate and serum level of FGF-23, while the CrePhex ${ }^{\Delta f l o x / y}$ and byp-mice exhibited increased production and serum levels of FGF-23, MEPE, and sFRP-4 (Figures 7 and 8). These observations provide the first successful attempt to our knowledge to discern whether integrated effects of these hormones or the activity of a single phosphatonin is essential for expression of the disease phenotype in byp-mice and affected patients with XLH. Indeed, the data suggest that increased bone production and serum levels of MEPE and sFRP-4 are not critical for development of the classical HYP phenotype (in the OC-Cre-Phex ${ }^{\Delta f l o x / y}$ mouse), whereas increased osseous production and serum FGF-23 concentration appear requisite for this biological function. Therefore, FGF-23 is likely the phosphatonin pivotal to the pathogenesis of XLH, and the role of MEPE and sFRP-4, if any, remains uncertain.

The concept of an abnormality in the production and serum level of a single phosphatonin as the requisite abnormality in bypmice and XLH seems virtually heretical. A variety of proteins, such as MEPE and sFRP-4, inhibit Pi transport, both in vitro and in vivo and influence bone and osteoblast mineralization. Moreover, in concert with a potential role as a phosphatonin, these proteins are produced by osteoblasts, markedly upregulated in the byp-mouse osteoblasts, and possibly activated directly or indirectly by Phex. Nevertheless, transgenic expression of FGF-23 (30) and a missense mutation of FGF-23 (31), which resists proteolytic cleavage and enhances biological activity, results in renal Pi wasting, abnormal vitamin D metabolism, rickets, and osteomalacia, identical to the phenotype observed in byp-mice and in patients with XLH. Moreover, Liu et al. (13) generated a combined FGF-23-deficient and 


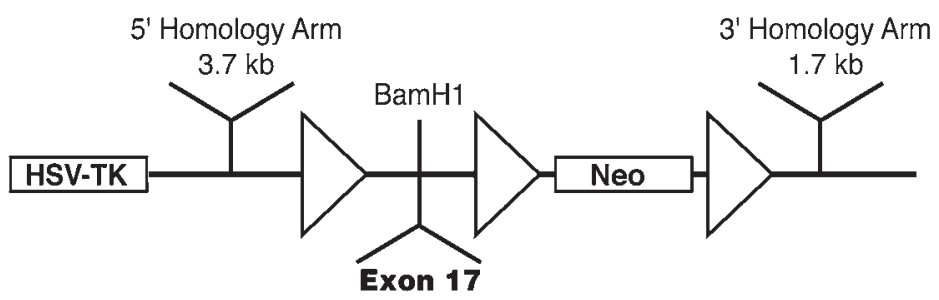

Figure 9

Generation of floxed Phex locus. Schematic structure of the targeting vector illustrates 3 loxP sites (triangles). Mutagenesis to the floxed Phex locus occurs upon $5^{\prime}$ and $3^{\prime}$ homologous recombination. Exon17 is inserted between loxP sites.
Phex-deficient hyp-mouse model, in which the characteristic hypophosphatemia, abnormal 1,25-dihydroxyvitamin $\mathrm{D}\left[1,25(\mathrm{OH})_{2} \mathrm{D}\right]$ levels, and rickets and osteomalacia generally associated with Phex deficiency were reversed. Consistent with our data, these results suggest that a singular abnormality in the production and circulating levels of FGF-23 is sufficient to cause both the renal and bone phenotypes in byp-mice.

In summary, therefore, use of Cre-loxP strategies enabled creation of global and osteoblast/osteocyte-specific knockout mice that are suitable for investigating Phex gene function in the regulation of Pi and vitamin D homeostasis, as well as bone histology. In contrast to the suggestion raised by previous studies in which targeted overexpression of Phex was studied, our observations provide compelling evidence that aberrant Phex function in osteoblasts and/or osteocytes alone is sufficient to underlie the biochemical and bone phenotype in bypmice, establishing osteoblast lineage cells as the physiologically relevant gene mutation site in XLH. Moreover, our data undeniably indicate that the effects of a single phosphatonin, FGF-23, acting downstream of Phex, may cause all elements of the characteristic elements comprising the renal and bone phenotypes in byp-mice.

\section{Methods}

\section{Normal and hyp-mice}

Six-week-old normal male C57BL/6J mice and C57BL/6J heterozygous hyp-mice purchased from The Jackson Laboratory and maintained at our laboratory were used in the present study.

\section{Generation of mice with the floxed Phex gene [Phex flox/+ $(\mathrm{Neo})$ and Phex flox/y $(\mathrm{Neo})]$}

We generated a mouse line with a floxed Phex gene (32-34) in which exon 17 was targeted for deletion in osteoblasts and osteocytes. We chose exon 17 for deletion, since previous studies documented that patients with XLH have missense mutations (2) and pseudoexon insertions (35) in this exon and it codes the zinc-binding site, a critical part of the protein catalytic site

\section{Figure 10}

Removal of Neo cassette and production of global (Cre$\left.P h e x^{\Delta f l o x / y}\right)$ knockout mice and targeted $P h e x^{f l o x /+\Delta n e o}$ mice. (A) Pups from genotype $\mathrm{F}_{0}$ heterozygous crossing with EIIACre mice were genotyped for the excision of floxed Phex. Female mosaics were mated with wild-type mice, producing variable excision of the 3 loxP sites and resulting in the Cre$P h e x^{\Delta f l o x / y}$ genotype (the global knockout mouse used in the

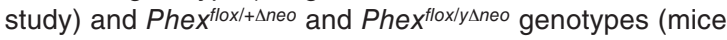
targeted for generation of Oc-Cre-Phex ${ }^{\Delta f l o x / y}$ mice). (B) The PCR strategy for mouse identification is depicted.
$(2,35,36)$ and an area included in the $3^{\prime}$ deletion of the byp-mice (5). This strategy assured that exon 17 excision, resulting in a frameshift, a premature termination codon, and truncated protein, would inactivate Phex.

Initially, we created a floxed targeting vector. Using primer pairs that specifically amplify exon 17 , we PCR screened DNA pools from the CITB murine SV/129 BAC library and identified a BAC clone containing Phex exon 17. Thereafter, we digested the BAC DNA from the clone with EcoR1, BamHI, HindIII, and SalI and electrophoresed the DNA fragments on an agarose gel, transferred the separated products to a nylon membrane, and used a radiolabeled exon $17 \mathrm{PCR}$ product for hybridization. We identified subclones containing gene fragments and prepared mini-libraries by digesting the BAC DNA with restriction enzymes and cloning appropriate fragments in the pBluescript $\mathrm{KS}^{+}$vector. Subsequently, we restriction mapped A
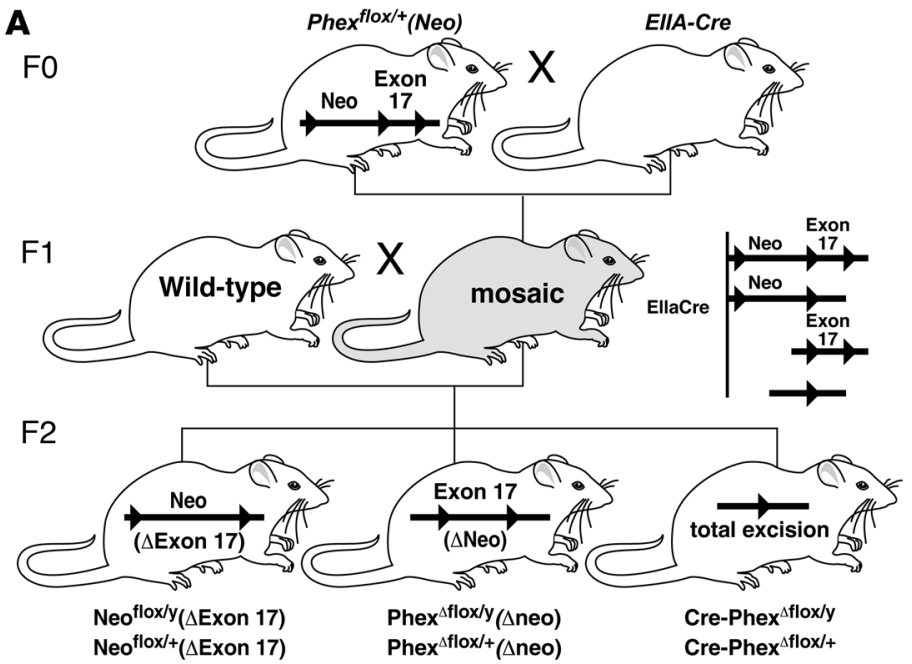

B
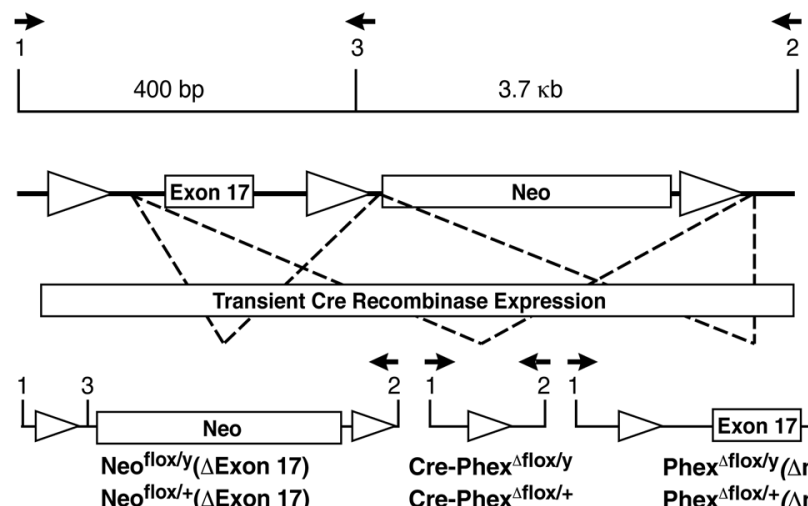

Cre-Phex ${ }^{\Delta \text { flox/+ }}$

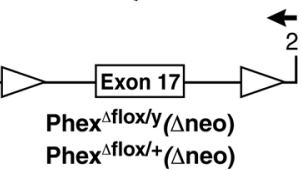

Primer 1: 5'-CCA CAG ATG TCT TGA GAC TGG-3'

Primer 2: 5'-GGC CAC TTG TGT AGC GCC-3'

Primer 3 (for F0 selection): 5'-ATA GCA GGC ATG CTG GGG ATG-3' 
the exon 17-bearing clones to identify appropriate DNA fragments for subcloning into the flox vector (37), which contained a TK cassette and a loxP site upstream of a BamHI restriction site and 2 loxP sites surrounding a Neo cassette downstream of the restriction site (Figure 9). The DNA identified, representing 3.7- and $1.7-\mathrm{kb}$ fragments adjacent to exon 17 (the $5^{\prime}$ and $3^{\prime}$ homology arms), was inserted upstream and downstream of the loxP sites, while a DNA fragment of Phex exon 17 was added at the BamHI site, surrounded by 2 loxP sites (Figure 9). We sequenced the inserted DNA to confirm identity and proper orientation. Using HindIII restriction sites, we linearized the floxed targeting vector (38), electroporated $25 \mu \mathrm{g}$ into R1 mouse male ES cells, and selected homologous or randomly integrated transformed cells by growth on G418 and GANK. To identify correctly targeted clones, we replicated and expanded approximately 450 selected colonies and isolated DNA from ES clones prior to digestion with BamHI, electrophoresis on agarose gels, and transfer to charged nylon membranes. Hybridization to a radiolabeled 5' probe, directed at DNA outside the targeting vector, identified potentially correctly targeted clones. We confirmed correct targeting by PCR and DNA sequence analysis, which revealed 3 loxP sites flanking exon 17 and the Neo cassette, and performed standard karyotype analysis to document haploidy.

We selected cells from correctly targeted clones, carrying the intermediate targeted Phex allele with the Neo cassette and containing the normal complement of 40 chromosomes, and injected them into the blastocoel cavities of E3.5 embryos from hyperovulated C57BL/6J mice. Surviving blastocysts were transferred into the oviducts of pseudopregnant recipient females. At birth, Phexf $f^{f o x /+}$ and Phexflox/y mice were selected by agouti spots, a marker of the ES genetic material, as well as by PCR selection using primers 1 (forward), 5'-CCACAGATGTCTTGAGACTGG-3', and 2 (reverse), 5'-GCAATCAGGCAGCCAAGTTCC-3', to detect transgenic homology, and the wild-type Phex gene as a positive control. The targeted insertion of loxP sites was detected by using primers 1 and 3 (reverse), $5^{\prime}$-ATAGCAGGCATGCTGGGGATG-3', as well as by primer 4 (forward), 5'-GGCCACTTGTGTAGCGCC-3', and primer 2 (Figure 10). The male chimeric founders identified were backcrossed with C57BL/6J females for 8 generations to ultimately obtain C57BL/6J floxed male and female progeny $\left[\mathrm{Phex}{ }^{f l o x /+}(\mathrm{Neo})\right.$ and $\left.\mathrm{Phex}{ }^{f l o x / y}(\mathrm{Neo})\right]$.

\section{Production of targeted and global Phex-knockout mice}

In subsequent breeding strategies, we removed the Neo cassette by crossing the Phex ${ }^{f l o x /+}(\mathrm{Neo})$ and Phexflox/y (Neo) mice with Ella-Cre mice purchased from the Jackson Laboratory (39), which generated genetically mosaic mice (Figure 10). Mating of female mosaic mice with normal male mice generated hemizygotic (Cre-Phex $\left.{ }^{\Delta f l o x / y}\right)$ and heterozygotic $\left(C r e-P h e x^{\Delta f l o x / x}\right)$ global Phex-knockout mice (Figure 10). The male hemizygotic mice with deletion of exon 17 in all tissues were used in all experiments.

The mating of the mosaic mice with normal mice also produced tar-

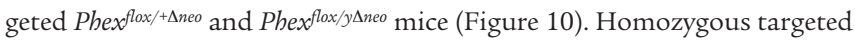

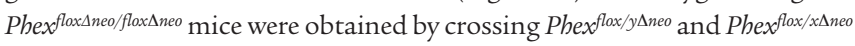
mice, and the osteoblast/osteocyte-specific (targeted) Phex-knockout

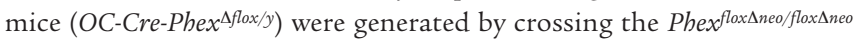
mice with C57BL/6J OC-Cre mice, produced by backcrossing the OC-Cre transgene from FVB-N mice (25) onto the C57BL/6J background for more than 7 generations. Since the osteocalcin-driven Cre recombinase enzyme is expressed only in osteoblasts and osteocytes (25), the floxed Phex gene deletion was confined to the osteoblasts and osteocytes. Except where noted, male hemizygotic mice with deletion of exon 17 in osteoblasts and osteocytes were used in the experiments.

The normal and byp-mice noted above and the knockout mice received a diet containing $0.6 \%$ calcium and phosphorus (Teklad Co.) and deionized water ad libitum from the time of weaning until study. For biochemical and histological studies, we used hemizygotic male byp- and global and targeted knockout mice. Care of mice met or exceeded the standards set forth by the NIH in the Guide for the care and use of laboratory animals (NIH publication no. 85-23. Revised 1985). The University of Wisconsin Animal Care and Use Committee approved all procedures.

\section{Biochemical measurements}

Mice were anesthetized by intraperitoneal injection of sodium pentobarbital, blood was collected though heart puncture, and serum samples were obtained by precipitation and centrifugation. Serum Pi levels were measured using a Phosphorus Liqui-UV kit from Stanbio Laboratory, as described previously (22). Serum calcium levels were assayed using a Calcium Liquicolor kit from Stanbio Laboratory following the protocol of the manufacturer. Serum intact FGF-23 levels were measured employing an FGF-23 ELISA kit obtained from Kainos Laboratories (40). As previously described, estimation of circulating MEPE levels was made by measurement of MEPE-ASARM (41) and serum sFRP-4 by a 2-antibody sandwich ELISA (15).

\section{Analytical methodology}

In vitro assay of murine renal $25(\mathrm{OH}) D$-1 $\alpha$-hydroxylase activity. We assayed the maximum velocity of renal $25(\mathrm{OH}) \mathrm{D}-1 \alpha$-hydroxylase activity in kidney homogenates by previously described methods $(22,42)$. Data are expressed as femtomoles per milligram (wet wt) kidney per minute.

Study of the renal $25(\mathrm{OH}) \mathrm{D}-1 \alpha$-hydroxylase activity, as well as mRNA and protein (see below) was accomplished in the various animal models in the baseline state and after PTH stimulation. The PTH was administered via surgically implantable Alzet osmotic minipumps (model 3001; Alza Corp.) as described previously (22). After 24 hours, the animals were sacrificed and their kidneys excised for measurement of enzyme activity, as well as $25(\mathrm{OH}) \mathrm{D}$-1 $\alpha$-hydroxylase mRNA and protein.

Phosphate uptake in renal brush border membranes. Renal brush border membrane vesicles were prepared from kidney cortex by $\mathrm{CaCl}_{2}$ precipitation as described previously (43) with modifications. Briefly, the kidneys were removed and washed free of blood with cold isotonic saline. The renal cortices were then isolated from the medulla and homogenized immediately in 30 volumes (vol/wt) of ice-cold $50 \mathrm{mM}$ mannitol/2 $\mathrm{mM}$ Tris-HCl buffer, $\mathrm{pH}$ 7.0. A 1- $\mathrm{M} \mathrm{CaCl}_{2}$ solution was added to the homogenate to a final concentration of $10 \mathrm{mM}$, and the mixture was stirred for 10 minutes at $4^{\circ} \mathrm{C}$. The homogenate was centrifuged at $3,000 \mathrm{~g}$ for 15 minutes, and the supernatant was decanted and centrifuged again at $43,000 \mathrm{~g}$ for 20 minutes. The pellet was washed one more time with the same buffer and centrifuged again for another 20 minutes at $43,000 \mathrm{~g}$. The final pellet was dissolved in incubation buffer containing $100 \mathrm{mM} \mathrm{NaCl}, 100 \mathrm{mM}$ mannitol, and 20 mM Tris-HEPES, pH 7.4.

The Pi uptake was assessed in quadruplicate using 40-60 $\mu \mathrm{g}$ of brush border membrane prepared as described above. The concentration of brush border membrane protein was measured and adjusted to $2-3 \mathrm{mg} / \mathrm{ml}$ using incubation buffer. A $20-\mu \mathrm{l}$ aliquot of brush border membrane suspension solution was used for each measurement, and 0.01-10 $\mathrm{mM} \mathrm{KH}_{2}{ }^{32} \mathrm{PO}_{4}$ $(9,000 \mathrm{Ci} / \mathrm{mmol}$; DuPont-NEW) was added for 1 minute followed by termination by $1 \mathrm{ml}$ of ice-cold stop solution ( $100 \mathrm{mM}$ mannitol/20 $\mathrm{mM}$ HEPES/Tris/0.1 mM KH $2 \mathrm{PO}_{4} / 20 \mathrm{mM} \mathrm{MgSO}_{4} / 100 \mathrm{mM}$ choline chloride). The final solution was separated by a premoistured filter $(0.45-\mu \mathrm{m}$ pore size) using the Millipore filtration method $(44,45)$. The filters were washed and associated ${ }^{32} \mathrm{P}$ measured by liquid scintillation spectroscopy

Real-time PCR assay of $m R N A$. We isolated total RNA from decapsulated whole mouse kidneys using the TRIzol protocol (Life Technologies Inc.), as described previously (22), and quantitated $25(\mathrm{OH}) \mathrm{D}-1 \alpha$-hydroxylase cytochrome P450 mRNA concentrations by real-time RT-PCR. Data were collected quantitatively, and the $\mathrm{Ct}$ number corrected by $\mathrm{Ct}$ readings of corresponding internal 18s rRNA controls. Data from a minimum of 6 
determinations (mean \pm SEM) are expressed in all experiments as fold changes compared with normal mice.

To isolate total RNA from bone, we euthanized mice and disarticulated the femurs. The femurs were trimmed of all fat, and the marrow was removed, frozen in liquid nitrogen, and stored at $-80^{\circ} \mathrm{C}$. To prepare the bone for RNA isolation, the samples were homogenized into fine powder in liquid nitrogen using a porcelain mortar and pestle. We extracted the total RNA from the resultant powder as described above and quantitated FGF-23, sFRP-4, and MEPE mRNA from the samples.

The detection of FGF-23 and sFRP-4 mRNA isolated from femur samples was performed using forward primers of 5'-CTGCTAGAGCCTATCCGGAC-3' (FGF-23, GenBank accession number NM_022657, 190-209 bp) and 5'-GTGCAAGTGCAAAAAGGTGA-3' (sFRP-4, GenBank accession number NM_016687.2, 804-823 bp) and reverse primers of 5'-AGTGATGCTTCTGCGACAA-3' (FGF-23, 528-510 bp) and 5'-ATCATCCTTGAACGCCACTC-3'(sFRP-4, 1,070-1,051 bp), combined with iTaq SYBR Green with ROX Detection Kit from Bio-Rad following reverse transcriptions as described above. Real-time detection of GAPDH mRNA signal (GenBank accession number XM_001476723.1; forward [308-327 bp]: 5'-GGTGTGAACCACGAGAAATA-3' , and reverse [767-748 bp]: $5^{\prime}$-TGAAGTCGCAGGAGACAACC-3') was also performed as the internal control for the amplification of FGF-23 mRNA and sFRP-4 mRNA. For MEPE mRNA, after the reverse transcription, the cDNA was amplified and detected by TaqMan MGB primer and probe (GenBank accession number NM_053172.1; forward [247-268 bp]: 5'-TGCTGCCCTCCTCAGAAATATC-3', reverse [382-305 bp]: 5'-GTTCGGCCCCAGTCACTAGA-3', and probe [270-284 bp]: 5'-CGCAGCCTGTAAAGA-3'). Internal control of $18 \mathrm{~S}$ rRNA (Applied Biosystems) was also amplified in separate tubes. Data were collected quantitatively and the $\mathrm{Ct}$ number was corrected by $\mathrm{Ct}$ readings of corresponding internal controls, either 18S rRNA or GAPDH. Data were then expressed as fold changes compared with experimental controls.

Western blot analysis. We measured $25(\mathrm{OH}) \mathrm{D}-1 \alpha$-hydroxylase and Npt2 protein in kidneys from the various animal models. Half-kidneys were rinsed free of blood with ice-cold saline and protein extracts prepared using a modified protocol described previously (22). Briefly, tissues were homogenized in sucrose buffer containing $20 \mathrm{mM}$ HEPES, $1 \mathrm{mM}$ EDTA, $255 \mathrm{mM}$ sucrose, 0.4 $\mathrm{mM}$ phenylmethylsulfonyl fluoride, and $2 \mu \mathrm{g} / \mathrm{ml}$ leupeptin. The homogenate was centrifuged at $1,500 \mathrm{~g}$ for 15 minutes, and the pellet containing mitochondrial protein, including $25(\mathrm{OH}) \mathrm{D}-1 \alpha$-hydroxylase, was resuspended in the same buffer, aliquoted, and stored at $-80^{\circ} \mathrm{C}$ until use. The supernatant that contained the plasma membrane protein obtained after centrifugation was also collected for the measurement of $\mathrm{Npt} 2$ protein.

A 20- $\mu$ g aliquot of the respective protein extracts was electrophoresed in $10 \%$ SDS-PAGE gel and transferred onto a nitrocellulose membrane. The membrane was then washed and probed with either 1:400 specific antimouse $25(\mathrm{OH}) \mathrm{D}-1 \alpha$-hydroxylase antibody $(46,47)$ or $1: 4,000$ anti-human Npt2 antibody (Alpha Diagnostic) and subsequently with 1:4,000 goat antirabbit IgG conjugated with HRP. To quantitate the immunoblotting signal, $6 \mathrm{ml}$ of chemiluminescence detection solution (ECL Plus; Amersham) was added, and the signal was detected directly by a fluorescence scanner (Storm 860; Amersham). The density of bands was analyzed using ImageQuant 5.2 software (Molecular Dynamics). The antibody was then stripped off by incubation in reprobing solution $(62.5 \mathrm{mM}$ Tris- $\mathrm{HCl}, 2 \%$ SDS, and $100 \mathrm{mM} 2$-mercaptoethanol, $\mathrm{pH}$ 6.7) for 30 minutes at $50^{\circ} \mathrm{C}$. The membrane was then blocked and probed with specific anti-cytochrome $c$ or $\beta$-actin antibody to verify the loading equivalence among samples.

\section{Bone structure and histomorphology}

High-resolution radiography ( $x$-ray) of the femur. To obtain high-resolution radiographs of the long bones (48), mouse femurs were extracted and incubated in lysis buffer $(2 \times$ SSC, $0.2 \%$ SDS, $10 \mathrm{mM} \mathrm{EDTA}, 10 \mathrm{mg} / \mathrm{ml}$ proteinase K) for 2 days. After the surrounding muscles were digested, the femurs were washed in PBS buffer and $\mathrm{x}$-rayed on a Faxitron model MX-20 Specimen Radiography System with a digital camera attached (Faxitron X-ray Corp.).

Double fluorochrome labeling of the long bone. To assess mineralization dynamics of the bone, double fluorescence bone labeling was accomplished as described previously (48). Briefly, a calcein label (5 mg/kg i.p.; Sigma-Aldrich) was administered to 6-week-old mice. This was followed by injection of an Alizarin red label ( $20 \mathrm{mg} / \mathrm{kg}$ i.p.; Sigma-Aldrich) 5 days later. Mice were sacrificed 48 hours after injection of the second label, and the femurs were removed and fixed in $2 \%$ paraformaldehyde and $2.5 \%$ glutaraldehyde at room temperature for 4 hours before serial dehydration. The specimens were then dehydrated through a graded series of ethanol (70\%-100\%) and embedded in MMA without prior decalcification. Sections of $50 \mu \mathrm{m}$ were cut using a Leitz 1600 saw microtome. The unstained sections were viewed under epifluorescent illumination using a Nikon PCM2000 confocal microscope, coupled to an Eclipse E800 upright microscope and interfaced with Osteomeasure histomorphometry software (version 4.1) to estimate mineralization dynamics.

Visualization of bone morphology by Goldner staining. Nondecalcified sagittal sections from femurs were stained using Goldner-Masson trichrome assay (48). Both cortical bone areas in the midshaft ( $2 \mathrm{~mm}$ proximal and $2 \mathrm{~mm}$ distal to the midshaft) were photographed using a Nikon microscope at 10x with Bioquant OSTEO v.7.20.10 (R\&M Biometrics) software. Unmineralized osteoid stains red, and mineralized bone, green/blue. Osteoid surface (\%) and osteoid volume (\%) were measured using an interactive image analysis system, which ensures unbiased sampling and averaging of areas (Bioquant R\&M Biometrics).

Visualization of bone morphology by procion red. This small molecule dye ( $0.8 \%$ procion red in sterile saline, $10 \mu \mathrm{l} / \mathrm{g}$ body weight) was injected 10 minutes prior to sacrifice through the tail vein. After sacrifice, the femurs were removed and fixed in 70\% ETOH followed by dehydration and embedded using a standard epoxy method (48). The specimens were sectioned at $100-\mu \mathrm{m}$ thickness using a Leitz 1600 saw microtome, viewed under a Nikon C100 confocal microscope, and photographed using an Optronics cooled CCD camera.

Resin-casted scanning electron microscopy. Femurs were dissected, fixed in $2 \%$ paraformaldehyde and $2.5 \%$ glutaraldehyde in $0.1 \mathrm{M}$ cacodylate buffer solution ( $\mathrm{pH} 7.4$ ) at room temperature for 4 hours, and then transferred to $0.1 \mathrm{M}$ cacodylate buffer solution. The specimens were dehydrated in ascending concentrations of ethanol, embedded in methyl-methacrylate, and then surface polished using $1 \mu \mathrm{m}$ and $0.3 \mu \mathrm{m}$ alumina alpha micropolish II solution (Buehler) in a soft cloth rotating wheel. The surface was acid etched with $37 \%$ phosphoric acid for 10 seconds, followed by $5 \%$ sodium hypochlorite for 5 minutes. The samples were then coated with gold and palladium as described previously (48) and examined using an FEI/Philips XL30 Field emission environmental scanning electron microscope.

Statistics. Data are expressed as the mean \pm SEM of at least 6 individual determinations. We evaluated the data statistically employing an ANOVA to test for any differences among the 4 groups of mice, followed, when a difference was determined, by 2 -sample $t$ tests in which all possible pairs of mice groups were evaluated. For the second-stage testing, the threshold for statistical significance was adjusted with a Bonferroni correction to compensate for multiple testing (49). A $P$ value of less than 0.05 is considered statistically significant.

\section{Acknowledgments}

This work was funded by NIH grants to M.K. Drezner (R01AR27032-26, 1K12RR017614, R01-SK65830-1, and M01-RR03186- 
21), P.S. Rowe (5R01-AR051598-05 and 7R03-DE015900-03), T.L. Clemens (R01-AR49410 and P30-AR046031), and R. Kumar (R01DK65830) and a Merit Review Grant from the Department of Veterans Affairs (to T.L. Clemens). The authors thank Xina Ying for valuable technical assistance; Stacy Sommer for performing FGF23 and sFRP-4 assays; Tobias Wolf for grant financial management; and Karen Stowe for secretarial services.

1. Rasmussen, H., and Tenenhouse, H.S. 1995. Mendelian hypophosphatemias. In The metabolic and molecular basis of inherited disease. C.R. Scriver, A.L. Beaudet, W.S. Sly, and D. Valle, editors. McGrawHill. New York, New York, USA. 3717-3745.

2. Holm, I.A., Huang, X., and Kunkel, L.M. 1997. Mutational analysis of the PEX gene in patients with X-linked hypophosphatemic rickets. Am.J. Hum. Genet. 60:790-797.

3. Du, L., et al. 1996. cDNA cloning of the murine Pex gene implicated in X-linked hypophosphatemia and evidence for expression in bone. Genomics. 36:22-28.

4. Rowe, P.S., et al. 1997. Distribution of mutations in the PEX gene in families with X-linked hypophosphataemic rickets (HYP). Hum. Mol. Genet. 6:539-549.

5. Beck, L., et al. 1997. Pex/PEX tissue distribution and evidence for a deletion in the $3^{\prime}$ region of the Pex gene in X-linked hypophosphatemic mice. J. Clin. Invest. 99:1200-1209.

6. Ruchon, A.F., et al. 1998. Pex mRNA is localized in developing mouse osteoblasts and odontoblasts. J. Histochem. Cytochem. 46:459-468.

7. Thompson, D.L., et al. 2002. Ontogeny of Phex/ PHEX protein expression in mouse embryo and subcellular localization in osteoblast. J. Bone Miner Res. 17:311-320.

8. Nesbitt, T., Coffman, T.M., Griffiths, R., and Drezner, M.K. 1992. Crosstransplantation of kidneys in normal and Hyp mice. Evidence that the Hyp mouse phenotype is unrelated to an intrinsic renal defect. J. Clin. Invest. 89:1453-1459.

9. Ecarot, B., Glorieux, F.H., Desbarats, M., Travers, R., and Labella, L. 1992. Defective bone formation by Hyp mouse bone cells transplanted into normal mice: evidence in favor of an intrinsic osteoblast defect. J. Bone Miner Res. 7:215-220.

10. Econs, M.J., and Drezner, M.K. 1994. Tumorinduced osteomalacia-unveiling a new hormone. N. Engl. J. Med. 330:1679-1681.

11. Bowe, A.E., et al. 2001. FGF-23 inhibits renal tubular phosphate transport and is a PHEX substrate. Biochem. Biophys. Res. Commun. 284:977-981.

12. Fukomoto, S., and Yamashita, T. 2002. Fibroblast growth factor- 23 is the phosphaturic factor in tumor-induced osteomalacia and may be phosphatonin. Curr. Opin. Nephrol. Hypertens. 11:385-398.

13. Liu, S., et al. 2006. Pathogenic role of Fgf 23 in Hyp mice. Am. J. Physiol. Endocrinol. Metab. 291:E38-E49.

14. Kumar, R. 2002. New insights into phosphate homeostasis: fibroblast growth factor 23 and frizzled-related protein- 4 are phosphaturic factors derived from tumors associated with osteomalacia. Curr. Opin. Nephrol. Hypertens. 11:547-553.

15. Berndt, T., et al. 2003. Secreted frizzled-related protein 4 is a potent tumor-derived phosphaturic agent. J. Clin. Invest. 112:785-794.

16. Argiro, L., Desbarate, M., Glorieux, F.H., and Ecarot, B. 2001. Mepe, the gene encoding a tumor-secreted protein in oncogenic hypophosphatemic osteomalacia, is expressed in bone. Genomics. 74:342-351.

17. Rowe, P.S., et al. 2004. MEPE has the properties of an osteoblastic phosphatonin and minhibin. Bone.
34:303-319.

18. Carpenter, T.O., et al. 2005. Fibroblast growth factor 7: an inhibitor of phosphate transport derived from oncogenic osteomalacia-causing tumors. J. Clin. Endocrinol. Metab. 90:1012-1020.

19. Liu, S., Guo, R., Tu, Q., and Quarles, L.D. 2002. Overexpression of Phex in osteoblasts fails to rescue the Hyp mouse phenotype. J. Biol. Chem. 277:3686-3697.

20. Bai, X., et al. 2002. Partial rescue of the Hyp phenotype by osteoblast targeted PHEX (phosphate-regulating gene with homologies to endopeptidases on the X chromosome) expression. Mol. Endocrinol. 16:2913-2925.

21. Erben, R.G., et al. 2005. Overexpression of human PHEX under the human $\beta$-actin promoter does not fully rescue the Hyp mouse phenotype. J. Bone Miner. Res. 20:1149-1160.

22. Yuan, B., Xing, Y., Horst, R.L., and Drezner, M.K. 2004. Evidence for abnormal translational regulation of renal 25 -hydroxyvitamin $\mathrm{d}-1 \alpha$-hydroxylase activity in the Hyp-mouse. Endocrinology. 145:3804-3812.

23. Miyamura, T., Tanaka, H., Inoue, M., Ichinose, Y., and Seino, Y. 2000. The effects of bone marrow transplantation on X-linked hypophosphatemic mice. J. Bone Miner. Res. 15:1451-1458.

24. Kuhn, R., Schwenk, F., Aguet, M., and Rajewsky, K. 1995. Inducible gene targeting in mice. Science. 269:1427-1429.

25. Zhang, M., et al. 2002. Osteoblast-specific knockout of the insulin-like growth factor (IGF) receptor gene reveals an essential role for IGF signaling in bone matrix mineralization. J. Biol. Chem. 277:44005-44012.

26. Shih, N.R, Jo, O.D., and Yanagawa, N. 2002. Effects of PHEX antisense in human osteoblast cells. J. Am. Soc. Nephrol. 13:394-399.

27. Ecarot, B., Glorieux, F.H., Desbarats, M., Travers, R., and Labelle, L. 1992. Effect of dietary phosphate deprivation and supplementation of recipient mice on bone formation by transplanted cells from normal and X-linked hypophosphatemic mice. J. Bone Miner. Res. 7:523-530.

28. Delvin, E.E., Richard, P., Desbarats, M., EcarotCharrier, B., and Glorieux, F.H. 1990. Cultured osteoblasts from normal and hypophosphatemic mice: calcitriol receptors and biological response to the hormone. Bone. 11:87-94.

29. Xiao, Z.S., et al. 1998. Intrinsic mineralization defect in Hyp mouse osteoblasts. Am. J. Physiol. 275:E700-E708.

30. Larsson, T., et al. 2004. Transgenic mice expressing fibroblast growth factor 23 under the control of the $\alpha 1$ (I) collagen promoter exhibit growth retardation, osteomalacia, and disturbed phosphate homeostasis. Endocrinology. 145:3087-3094.

31. Shimada, T., et al. 2002. Mutant FGF-23 responsible for autosomal hypophosphatemic rickets is resistant to proteolytic cleavage and causes hypophosphatemia in vivo. Endocrinology. 143:3179-3182.

32. Deng, C., Thomas, K.R., and Capecchi, M.R. 1993. Location of crossovers during gene targeting with insertion and replacement vectors. Mol. Cell. Biol.
13:2134-2140.

33. Braun, R.E., et al. 1990. Infertility in male transgenic mice: disruption of sperm development by HSV-tk expression in postmeiotic germ cells. Biol. Reprod. 43:684-693.

34. Yang, X., Li, C., Xu, X., and Deng, C. 1998. The tumor suppressor SMAD4/DPC4 is essential for epiblast proliferation and mesoderm induction in mice. Proc. Natl. Acad. Sci. U. S. A. 95:3667-3672.

35. Dixon, P.H., et al. 1998. Mutational analysis of PHEX gene in X-linked hypophosphatemia. J. Clin. Endocrinol. Metab. 83:3615-3623.

36. Hruska, K.A., et al. 1995. X-linked hypophosphatemic rickets and the murine Hyp homologue. Am. J. Physiol. 268:F357-F362.

37. Marth, J.D. 1996. Recent advances in gene mutagenesis by site directed recombination. J. Clin. Invest. 97:1999-2002.

38. Ramirez-Solis, R., Davis, A.C., and Bradley, A. 1993. Gene targeting in embryonic stem cells. Methods Enzymol. 225:855-878.

39. Xu, X., et al. 2001. Direct removal in the mouse of a floxed neo gene from a three-loxP conditional knockout allele by two novel approaches. Genesis. 30:1-6.

40. Yamazaki, Y., et al. 2002. Increased circulatory level of biologically active full-length FGF-23 in patients with hypophosphatemia rickets/osteomalacia. J. Clin. Endocrinol. Metab. 87:4957-4960.

41. Bresler, D., Bruder, J., Mohnike, K., Fraser, W.D., and Rowe, P.S. 2004. Serum MEPE-ASARM-peptides are elevated in X-linked rickets (HYP): implications for phosphaturia and rickets. J. Endocrinol. 183:R1-R9.

42. Reinhardt, T.A., Horst, R., Orf, J.W., and Hollis, B.W. 1984. A microassay for 1,25-dihydroxyvitamin D not requiring high performance liquid chromatography: application to clinical studies. J. Clin. Endocrinol. Metab. 58:91-98.

43. Malathi, P., Preiser, H., Fairclough, P., Mallett, P., and Crane, R.K. 1979. A rapid method for the isolation of kidney brush border membranes. Biochim. Biophys. Acta. 554:259-263.

44. Tenenhouse, H.S., and Scriver, C.R. 1978. The defect in transcellular transport of phosphate in the nephron is located in brush-border membranes in X-linked hypophosphatemic (Hyp mouse model). Can. J. Biochem. 56:640-646.

45. Nakagawa, N., Arab, N., and Ghishan, F.K. 1991. Characterization of the defect in the Na+-Phosphate transporter in vitamin D-resistant hypophosphatemic mice. J Biol. Chem. 266:13616-13620.

46. Zehnder, D., et al. 1999. Expression of 25hydroxyvitamin $\mathrm{D}_{3}-1 \alpha$-hydroxylase in the human kidney. J. Am. Soc. Nephrol. 10:2465-2473.

47. Zehnder, D., et al. 2001. Extrarenal expression of 25-hydroxyvitamin $\mathrm{D}_{3}-1 \alpha$-hydroxylase. J. Clin. Endocrinol. Metab. 86:888-894.

48. Feng, J.Q., et al. 2006. Loss of DMP1 causes rickets and osteomalacia and identifies a role for osteocytes in mineral metabolism. Nat. Genet. 38:1310-1315.

49. Neter, J., and Wasserman, W. 1974. Applied linear statistical models. Richard D. Irwin Inc. Homewood, Illinois, USA. 842 pp. 